\title{
Interactions of Nucleic Acid Bases with Temozolomide. Stacked, Perpendicular, and Coplanar Heterodimers
}

\author{
Okuma Emile Kasende* \\ Faculty of Science University of Kinshasa, \\ B.P. 190 Kinshasa XI, D. R. Congo \\ okuma.kasende@unikin.ac.cd \\ Vincent de Paul N. Nziko, Steve Scheiner*,a \\ Department of Chemistry \& Biochemistry Utah State University, \\ Logan, UT 84322-0300, USA \\ steve.scheiner@usu.edu
}

\begin{abstract}
Temozolomide (TMZ) was paired with each of the five nucleic acid bases, and the potential energy surface searched for all minima, in the context of Dispersion-Corrected Density Functional Theory and MP2 methods. Three types of arrangements were observed, with competitive stabilities. Coplanar H-bonding structures, reminiscent of Watson-Crick base pairs were typically the lowest in energy, albeit by a small amount. Also very stable were perpendicular arrangements that included one or more H-bonds. The two monomers were stacked approximately parallel to one another in the third category, some of which contained weak and distorted H-bonds. Dispersion was found to be a dominating attractive force, largest for the stacked structures, and smallest for the coplanar dimers.
\end{abstract}

${ }^{a}$ telephone (435) 797-7419 


\section{INTRODUCTION}

The temozolomide (TMZ) molecule pictured in Scheme 1 is attracting growing attention by numerous research groups by virtue of its ability to serve as a DNA alkylating agent. ${ }^{1-3}$ Purines are the most common alkylation target, in particular O6 and N7 of guanine, and N3 of adenine. As the most successful antiglioma drug, TMZ can add several months to the life expectancy of malignant glioma patients. ${ }^{1-9}$ Glioblastoma, or malignant glioma (MG), is the most aggressive adult brain cancer and accounts for more than $50 \%$ of all glioma cases diagnosed. ${ }^{10}$ Despite research efforts, the average lifespan for a MG patient postdiagnosis is 14.6 months with most patients experiencing tumor relapse and outgrowth within 7 months of initial radiation therapy. ${ }^{11-13}$

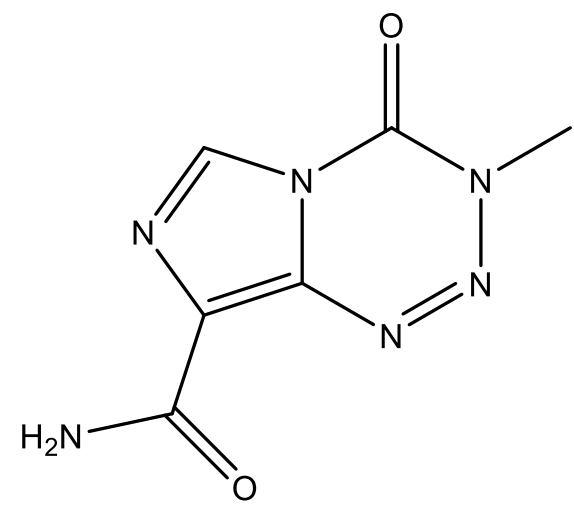

Scheme 1. Structure of temozolomide

Basically, the TMZ molecule is characterized by a fused pair of heterocyclic rings containing a total of five $\mathrm{N}$ atoms, as well as a carbonyl and a carboxamide group. Such a structure can be expected to participate in hydrogen bonds (HBs) or dispersion-dominated interactions with other molecules. Because of the ubiquitous nature of noncovalent interactions (NCIs) in many biological systems, ${ }^{14-29}$ these NCIs may serve to enhance the anticancer potency of TMZ by fostering its interaction with other pharmacologic agents. Previous work from this laboratory has examined the interactions of $\mathrm{TMZ}$ with both small molecules $\mathrm{H}_{2} \mathrm{O}, \mathrm{HCl}, \mathrm{BH}_{3}$, and $\mathrm{BF}_{3}$, as well as larger pharmacological agents chloroquine and quercetin, as well as possible homodimers of $\mathrm{TMZ}^{30-35}$ The preferred geometries of the heterodimers of TMZ with both water and $\mathrm{HCl}$ are guided by standard $\mathrm{H}$-bond considerations. The $\mathrm{O}$ atom of the terminal amide group is the primary atom of attack, with an interaction energy exceeding $30 \mathrm{~kJ} / \mathrm{mol} . \mathrm{BH}_{3}$ and $\mathrm{BF}_{3}$ act as Lewis acids and quite strongly, with interaction energies in the $60-100 \mathrm{~kJ} / \mathrm{mol}$ range. On the 
other hand, when interacting with other molecules containing aromatic moieties, stacked arrangements are generally preferred to H-bonded arrangements, although not necessarily by a large margin.

Since TMZ may well interact directly with nucleic acid bases, it is important to examine how such interactions might occur. What sort of complexes are to be expected, and how strong might be the binding? The structure of TMZ presents the interesting possibility that it might bind with each of the nucleic acid bases by multiple H-bonds, very much akin to the Watson-Crick base pairing that occurs within DNA. Are there alternate modes of binding in addition to the most stable complexes, and how much higher in energy might these be? Does TMZ prefer to bind with certain of the nucleic acid bases in competition with others, and if so, how strong is this preference? From a more fundamental perspective, these interactions raise interesting questions concerning the relative strength of HBs in comparison with other NCIs such as dispersiondominated stacking of aromatic systems. Moreover, the presence within TMZ of a large number of heteroatoms, for example more $\mathrm{N}$ atoms than $\mathrm{C}$, makes it a particularly interesting subject in a fundamental sense.

At this juncture, there has been neither experimental nor theoretical examination of the interaction between TMZ and the various nucleic acid bases, either within the context of Hbonding or in any other manner. This work is designed to address these questions via quantum chemical methods. Each of the nucleic acid bases is paired with TMZ and a thorough search identifies numerous minima on the potential energy surface. The nature of the bonding within each complex is elucidated, as is the strength of the interaction, leading to answers to questions concerning molecular recognition as well as the nature of noncovalent forces. While the data below are specifically relevant to TMZ, the trends and physical phenomena may be considered as relevant to other related molecules, aromatic systems with polar substituents.

\section{COMPUTATIONAL METHODS}

Three pyrimidines, cytosine (C), thymine (T), and uracil (U) were examined along with two purines adenine (A) and guanine (G), shown in Scheme 2. It may be recalled that the pyrimidines bases comprise several tautomers. Cytosine, for example, has three major tautomeric forms, which have different properties: enol, keto, and keto-imine. The latter is unstable in the gas phase, requiring solvation for its stability, and the enol tautomer is slightly more stable than the keto form by about $0.03 \mathrm{eV} .{ }^{36-38}$ Although uracil and thymine may exist in 
six tautomeric forms, all the experimental results so far available are consistent with the diketo tautomer being the most stable tautomer in the condensed or gas phase. ${ }^{39-44}$
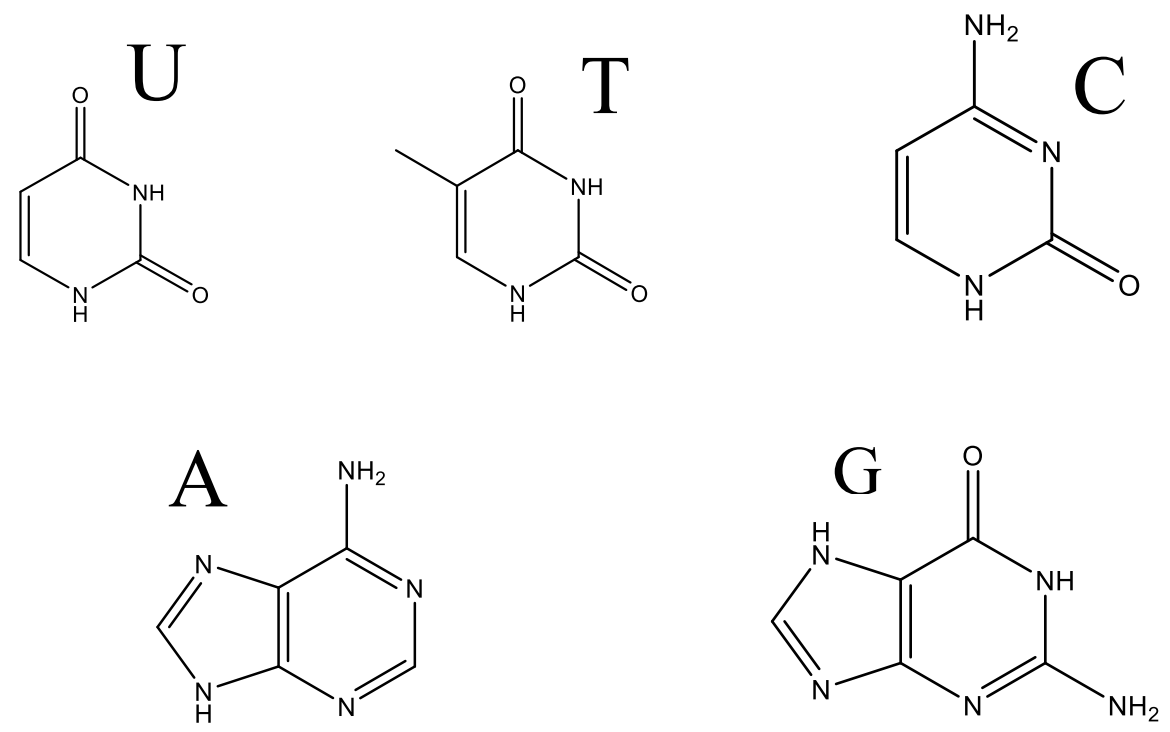

Scheme 2. Structures of nucleic acids

Numerous theoretical studies devoted to the tautomeric equilibria of guanine indicate that amongst 15 possible tautomer structures, there are four low-energy tautomers (amino-oxo and amino-hydroxy) with the amino-oxo form having hydrogen at N7 as the most stable gas-phase tautomer. ${ }^{45-51}$ Nevertheless, the second most stable form, keto-N9H, is the form in Watson-Crick base-pairing in DNA. The tautomeric landscape of adenine is somewhat less complex than is the case of guanine because of the absence of the oxygen. Experimental investigations ${ }^{52,53}$ reported two amino tautomers, with the $9 \mathrm{H}$ form most abundant and also present in DNA and RNA; $7 \mathrm{H}$ form has only a small presence. Of course, when placed within the context of nucleic acids, certain of the many tautomers of these bases previously investigated would be precluded by attachment to the relevant sugars, or by other considerations. In any case, the tautomeric form chosen for all bases here is that which is fundamentally the most stable, without the influence of solvation effects.

All calculations employed the $6-31+\mathrm{G}(\mathrm{d}, \mathrm{p})$ basis set. The geometries of the dimers were fully optimized using the M06-2X functional. Vibrational analysis verified each structure as a true 
minimum. Single point calculations of these heterodimers were carried out with the B3LYP, B3LYP-D3, $\omega$ B97-XD, and MP2 protocols. ${ }^{54-63} 100$ random geometries generated by a home program (Department of Chemistry and Biochemistry, Utah State University) were taken as starting points, leading to the minima described below. The binding energy BE of each complex was derived as an electronic energy difference between the optimized dimer and the sum of the monomers in their optimized geometries. This binding energy was corrected for basis set superposition error (BSSE) ${ }^{64}$ using the Boys-Bernardi counterpoise correction. ${ }^{65}$

The dispersion energy was estimated as the difference in binding energy between B3LYP-D3 and B3LYP as described by Equation (1). The molecular electronic energies E were computed by dispersion-corrected DFT given by Equation (2), in which $\mathrm{E}_{\mathrm{DFT}}$ is the (all-electron) KS-DFT energy for a particular density functional, $\mathrm{E}^{(2)}$ disp is the standard atom pair-wise London dispersion energy from D3 theory ${ }^{66}$ (using Becke-Johnson damping), ${ }^{67-69}$ and $\mathrm{E}^{(3)}$ disp is a threebody dispersion term (of Axilrod-Teller-Mutto type) ${ }^{70,71}$ which was calculated as described in reference ${ }^{66}$ using program DFT-D3. ${ }^{72}$

$$
\begin{aligned}
& \text { Disp }=\mathrm{BE}_{(\mathrm{B} 3 \mathrm{LYP}-\mathrm{D} 3)}-\mathrm{BE}_{(\mathrm{B} 3 \mathrm{LYP})} \\
& \mathrm{E}=\mathrm{E}_{\mathrm{DFT}}+\mathrm{E}^{(2)}{ }_{\text {disp }}+\mathrm{E}_{\text {disp }}^{(3)}
\end{aligned}
$$

Calculations were performed using the Gaussian 09 software package. ${ }^{73}$ Atomic charges and charge transfer energies were assessed by NBO 6.0 software. ${ }^{74}$ GaussView and Chemcraft programs were used for visualization. ${ }^{75}$

The molecular electrostatic potential (MEP) was evaluated for the monomers in their optimized geometry at the M06-2X /6-31+G(d,p) level. Electron density shifts caused by complexation were calculated as the difference between the electron density of the complex and the sum of those of the monomers, again in the geometry within the complex.

\section{RESULTS}

\section{Pyrimidines}

The binding energies of the minima identified on the heterodimer potential energy surfaces of TMZ with uracil, thymine, and cytosine are respectively listed in Tables 1, 2, and 3. They are ordered by their stability at the M06-2X level, but this order can differ with the other levels considered here. Also reported in the tables are the NBO charge transfer energies $\mathrm{E}(2)$ that exceed a criterion of $2 \mathrm{~kJ} / \mathrm{mol}$. The largest $\mathrm{E}(2)$ values generally refer to particular HBs. 
For both $\mathrm{U}$ and $\mathrm{T}$, the most stable dimer is a coplanar structure, both illustrated in Fig 1. The dominant stabilizing force is a pair of $\mathrm{NH} \cdot \mathrm{O}$ HBs. A similar structure is quite stable for cytosine, but this geometry is slightly less stable than $\mathrm{C} 1$ at the M06-2X level, so is labeled C2.

Note though, that $\mathrm{C} 2$ is more stable than $\mathrm{C} 1$ at the other three levels of theory, and by substantial margins. T1 and U1 are clearly the most stable, at all levels of theory. One may therefore conclude that these coplanar doubly H-bonded dimers are probably preferred for all three pyrimidines. The HBs are rather short, between 1.74 and $1.960 \AA$, and with $\mathrm{E}(2)$ values between 72 and $138 \mathrm{~kJ} / \mathrm{mol}$. The latter quantities are large, exceeding the total binding energy in certain cases. This distinction is a reminder that $\mathrm{E}(2)$ provides only a qualitative measure of charge transfer, and is not equivalent to the full induction energy which might be assessed via symmetry-adapted perturbation theory, for example, or other energy decomposition schemes.

The next most stable structure can be described as a T-shape, wherein the planes of the two molecules are roughly perpendicular $(\mathrm{P})$ to one another, as illustrated in Fig 2 . The most obvious noncovalent bond is a bifurcated HB wherein the NH proton of the pyrimidine is shared between the $\mathrm{O}$ and $\mathrm{N}$ atoms of the TMZ. The former is located on the amide group of $\mathrm{TMZ}$ and the latter on its six-membered ring. The NH donor is a ring NH for U2, T2, and C3, but utilizes the pendant amino group in $\mathrm{C} 1$. The $\mathrm{NH} \cdot \cdot \mathrm{O}$ HB tends to be a bit shorter than $\mathrm{NH} \cdot \mathrm{N}$ but all are 2.4 $\AA$ or less. $\mathrm{E}(2)$ values for these HBs are 25 and $12 \mathrm{~kJ} / \mathrm{mol}$ for the $\mathrm{NH} \cdot \cdot \mathrm{O}$ and $\mathrm{NH} \cdot \cdot \mathrm{N} H B s$, respectively for $\mathrm{U} 2$ and $\mathrm{T} 2$, but a bit smaller for $\mathrm{C} 1$ and $\mathrm{C} 3$. It might finally be noted that $\mathrm{C} 1$ is estimated to be only about $2-4 \mathrm{~kJ} / \mathrm{mol}$ more stable than $\mathrm{C} 3$.

Another prime motif is a stacked geometry where the planes of the two molecules are roughly parallel to one another. This general structure can be divided into two subcategories. There are those of the type S1 illustrated in Fig 3, where the arrangement is stabilized by a pair of HBs on either end of the dimer. In most cases, these two $\mathrm{HBs}$ are of $\mathrm{NH} \cdots \mathrm{O}$ and $\mathrm{CH} \cdots \mathrm{O}$ type, the former shorter and stronger than the latter. In dimer $\mathrm{U} 3$, for example, the $\mathrm{NH} \cdots \mathrm{O} \mathrm{HB}$ is $1.994 \AA$ in length, with $\mathrm{E}(2)=44 \mathrm{~kJ} / \mathrm{mol}$, counting electron donation from both the $\mathrm{O}$ lone pairs and the related $\pi(\mathrm{CO})$ bond into $\sigma^{*}(\mathrm{NH})$. The $\mathrm{CH} \cdots \mathrm{O} \mathrm{HB}$ is shorter, $2.518 \AA$, and $\mathrm{E}(2)$ less than $6 \mathrm{~kJ} / \mathrm{mol}$. S1 geometries U3 and T3 are roughly $5-7 \mathrm{~kJ} / \mathrm{mol}$ less stable than the P structures U2 and T2; C4 is higher in energy than the most stable perpendicular arrangement $\mathrm{C} 1$ by $1-6 \mathrm{~kJ} / \mathrm{mol}$. (The $\mathrm{S} 1$ designation is also used below to refer to stacked structures with a single HB between molecules.) 
There are also a set of stacked structures that do not have the benefit of significant HBs. The most stable of these S2 configurations are displayed in Fig 4. T4 contains the semblance of a $\mathrm{CH} \cdots \mathrm{O} \mathrm{HB}$ but this bond is quite weak, with $\mathrm{R}=2.59 \AA$ and $\mathrm{E}(2)$ only $3.3 \mathrm{~kJ} / \mathrm{mol}$; neither U4 nor C5 contain a HB of any sort. The absence of a significant HB reduces the stability of these S2 geometries by a variable amount. For example U4 is higher in energy than $\mathrm{U} 3$ by $7 \mathrm{~kJ} / \mathrm{mol}$ at the B3LYP-D3 level but is essentially equally stable with M06-2X. On the other hand T4 is clearly less stable than T3 by amounts varying between 3 and $10 \mathrm{~kJ} / \mathrm{mol}$.

Comparison of the energetic data suggests there is little distinction between $\mathrm{T}, \mathrm{U}$, and $\mathrm{C}$ with regard to the maximal binding energy of TMZ. The three DFT methods suggest this quantity is on the order of $70-78 \mathrm{~kJ} / \mathrm{mol}$; the MP2 maximal binding energy is a bit smaller, roughly 51-55 $\mathrm{kJ} / \mathrm{mol}$.

$\underline{\text { Purines }}$

The energies and NBO characteristics of the complexes of TMZ with the purines A and G are reported in Tables 4 and 5. In both cases, there is some ambiguity concerning the identity of the global minimum. While A1 is slightly preferred over A2 for M06-2X, the latter is more stable for the other three levels of theory; there is similar ambiguity for G1 vs G2. The structures of these dimers are illustrated in Figs 5 and 6. A1 and G1 place the two molecules approximately perpendicular to one another. Both are stabilized by HBs wherein NH of the purine participates in a bifurcated $\mathrm{HB}$ with $\mathrm{O}$ and $\mathrm{N}$ atoms of TMZ. G5 also has this same general structure, but is considerably less stable than is G1. A2 and G2, on the other hand each contain a pair of classic HBs.

A digestion of the binding energies leads to the conclusion that the perpendicular and HB structures of the purine-TMZ dimers are competitive with one another regarding the global minimum. The two HB structures A2 and G2 contain strong H-bonding, with E(2) surpassing 75 $\mathrm{kJ} / \mathrm{mol}$, and ranging up to as high as $137 \mathrm{~kJ} / \mathrm{mol}$. The HBs in the perpendicular dimers are considerably weaker, with E(2) less than $60 \mathrm{~kJ} / \mathrm{mol}$. The stacked structures are a bit less stable, whether or not they contain elements of H-bonding. For example, the S1 A structures A3 and A4 shown in Fig 7, are more stable than S2 A5 in Fig 8. The situation is less clear cut for the guanine dimers, in that G3 is predicted to be more stable than G4 by M06-2X even though the former does not contain a HB; the ordering reverses for the other three levels of theory. A comparison of the $\mathrm{A}$ and $\mathrm{G}$ dimers indicates that $\mathrm{G}$ engages in more strongly bound complexes 
with TMZ than does A. The outlier in this analysis arises from MP2 calculations, where there is little distinction between the binding energies of the global $\mathrm{A}$ and $\mathrm{G}$ minima.

In terms of a comparison between the purines and pyrimidines, there appears to be no obvious distinction in maximal binding energy with TMZ that is visible across the spectrum of all four theoretical methods, although there is some agreement concerning the preference of TMZ for $\mathrm{G}$.

\section{Electrostatic Considerations}

One of the prime forces that controls the geometry adopted by dimers of this sort arises from Coulombic forces. A convenient means to visualize this anisotropic component of the interaction is via molecular electrostatic potentials (MEPs) of the individual monomers. The blue and red regions of the MEPs of the five bases and TMZ in Fig 9 respectively indicate the most positive and negative regions. In general, red negative regions occur around heteroatoms, more so for $\mathrm{O}$ than for $\mathrm{N}$. The areas surrounding the $\mathrm{H}$ atoms are typically positive, especially for those $\mathrm{H}$ atoms bonded to $\mathrm{N}$. These patterns are conducive to the formation of the various $\mathrm{HBs}$ observed in the various dimers, wherein $\mathrm{NH}$ is a superior proton donor to $\mathrm{CH}$.

With regard to the regions above and below the planes of the various molecules, these regions are largely neutral, signified by the green colors. TMZ, on the other hand has a blue region above its six-membered ring which ought to attract the negative region of a partner molecules. And indeed, a glance at some of the $\mathrm{P}$ dimers shows a propensity for the $\mathrm{O}$ atom of the pyrimidine to lie directly above this region of TMZ. U2, T2 and C3 represent examples of this arrangement. $\mathrm{C} 1$ is similar except that it is the $\mathrm{N}$ atom of $\mathrm{C}$ that occupies this position. With respect to the purines, $\mathrm{A} 1$ places the $\mathrm{N}$ atom of adenine above the TMZ, and the $\mathrm{O}$ atom of guanine takes its place in G1. One can conclude that the positive region above TMZ adds to the stability of the $\mathrm{P}$ dimers via its attraction for $\mathrm{O}$ and $\mathrm{N}$ atoms of the DNA bases.

\section{Charge Shifts}

Molecular interactions of the sort considered here usually have associated with them shifts of electron density. That is, the electric fields generated by one monomer induce displacements of the electron cloud of its partner, and vice versa. Certain of these charge shifts can be quantified by NBO formalism, where the populations of individual orbitals are altered. But a more universal and spatial picture of these density redistributions can be envisioned by density difference maps. 
Fig 10 displays the difference in density between the full complex, and the sum of unperturbed densities of the two constituent monomers, each prior to any interaction between the two subunits. The purple regions indicate density increases, while losses are shown in green. The systems chosen for display are the four most stable dimers of TMZ with thymine, which represent each of the four categories of geometry observed here. The dominant characteristics of each system is the fingerprint of a HB which consists of the (green) loss of density around the bridging proton and the corresponding (purple) gain in the lone pair region of the proton acceptor atom. The intensities of the charge changes, as signified by the extent of each region, are roughly proportional to the strength of each $\mathrm{HB}$, and inversely related to the HB length. The categorization of T4 as an S2 structure is confirmed by the absence of any visible charge shift along the weak $\mathrm{CH} \cdot \cdot \mathrm{N} \mathrm{HB}$. Electron density shift patterns in the dimers of TMZ with the other nucleic acid are consistent with those illustrated for thymine in Fig 10.

Influence of Dispersion

It is of course obvious that HBs provide a strong stabilizing force. On that basis, one might have anticipated that the HB structures ought to be the most stable dimers, and by a sizable margin. In the case of the pyrimidines, HB geometries do appear to represent the global minima, but this is not always the case. For example, the $\mathrm{C} 1$ perpendicular dimer of cytosine with $\mathrm{TMZ}$ is predicted by M06-2X to be the most stable. In the case of the purines, the perpendicular dimer is competitive with, and in some instances more stable than, the HB geometry. And even when a HB dimer is the lowest energy structure, it is typically only a few $\mathrm{kJ} / \mathrm{mol}$ more stable than the next lowest structure. Then there are the stacked geometries, some of which have no HB at all, yet are only slightly higher in energy than those with one or more strong HBs.

The most obvious factor in the stability of dimers with weak or nonexistent HBs is dispersion energy. This attractive force is expected to be greatest for stacked geometries where the faces of the aromatic systems of the two molecules are in close contact. A straightforward means of extracting the dispersion energy is by direct comparison of B3LYP-D3 where dispersion is explicitly included with B3LYP where it is not. The binding energies by these two methods are displayed in Tables 6-8 for the U, T, and C dimers. The third column reports their difference which may be taken as a reasonable approximation of the dispersion energy. (While B3LYP may implicitly contain a small portion of the dispersion implicitly, the D3 correction accounts for the lion's share of this quantity.) 
One sees a clear pattern emerge from this data. The stacked dimer types, S1 and S2, show dispersion energies in the range between and 51 and $64 \mathrm{~kJ} / \mathrm{mol}$. The range for the perpendicular structures is smaller, 33 - 40, and that for the coplanar HB dimers is smaller still at 12 - 20. In other words, the stacked geometries have an enormous dispersion advantage over the HB dimers, by some $30-50 \mathrm{~kJ} / \mathrm{mol}$, enough to counter the stabilizing effects of HB. Very similar trends are noted in the purine dimers, as shown in Tables 9 and 10. The range of dispersion energy is 55 $74 \mathrm{~kJ} / \mathrm{mol}$ for stacked, a bit larger than the pyrimidine stacked values, likely due to the larger size of the purines. The ranges of $36-39 \mathrm{~kJ} / \mathrm{mol}$ for perpendicular and $13-16$ for coplanar $\mathrm{HB}$, are quite similar to the pyrimidine ranges.

Closer inspection of Tables 6-10 reveals that one can say that certain configurations owe their stability solely to dispersion. U7 in Table 6 , for example, has a positive binding energy at the B3LYP level, as do T4 and T6, C7 and C8, and several others. These instances of dispersion domination are all examples of stacked geometries, so the importance of dispersion is not a surprise. This dispersion pulls the two monomers closer together than would occur in its absence, leading to the positive values for certain dimers in Tables 6-10.

There is a remaining question concerning the accuracy of the calculations presented here. In order to assess how much the results might be affected by a larger basis set, the binding energies of all 12 of the uracil/TMZ dimers were recomputed using the much larger cc-pVTZ and aug-ccpVTZ basis sets, in the context of the M06-2X functional. As in the earlier cases, counterpoise corrections were applied to each. For purposes of consistency, the same geometries were used for each basis set, that originally generated by $6-31+\mathrm{G}^{* *}$ and used in the discussions above. As is evident in Fig 11, the enlargement of the basis set produces a small diminution in the absolute value of the binding energy. But most importantly, the trends in these values are unaffected: the rising pattern from left to right of the black $6-31+\mathrm{G}^{* *}$ basis set is echoed by the larger sets as well.

Another issue relates to the environment. The calculations described above place the two molecules in an isolated situation so as to extract the most fundamental aspects of their interaction. There is the question as to whether the surroundings might alter the conclusions. To test this notion, each of the three most stable TMZ/uracil dimers were placed in a polarizable continuum, ${ }^{76-78}$ characterized by a dielectric constant of 4.2 , a value that is consistent with other studies of such effects in a biological context. ${ }^{79-86}$ These three dimers represent each of the 
classes of interactions observed here, HB, P, and S, respectively. Calculations were carried out at both the M06-2X and B3LYP-D3 levels. Although the absolute values of the binding energies were diminished by this environment, the relative order: $\mathrm{U} 1<\mathrm{U} 2<\mathrm{U} 3$ remained unchanged at either level of theory.

\section{DISCUSSION}

It is not uncommon to observe aromatic dimers arrange themselves in parallel/stacked geometries as well as perpendicular T-shaped structures. Examples of pure aromatic systems

with no H-bonding or even polar substituents include benzene, naphthalene, and anthracene ${ }^{87,88}$ where the two dimer geometry types are of comparable energy. Due in part to its larger size, the binding energy of the stacked naphthalene dimer is calculated at the $\operatorname{CSD}(\mathrm{T})$ level to be some $24 \mathrm{~kJ} / \mathrm{mol}$, roughly three times larger than that of benzene. Indeed, the latter represents a more general rule ${ }^{87}$ that as the molecules grow in size, there is an increasingly favorable stability of parallel over perpendicular geometry.

With the introduction onto the aromatic system of heteroatoms and pendant groups with the capability to engage in HBs, this type of noncovalent bond can effectively compete with the forces that drive the system toward either parallel or perpendicular geometry. The results of this competition for the systems studied here result in a general preference for coplanar H-bonded dimers, but the energies of these structures are only marginally more favorable than those of perpendicular and parallel arrangements. Although there are some disagreements amongst the theoretical methods employed here, the coplanar HB structures are generally most stable, followed by perpendicular, and then by stacked. Of course, the stacked geometries do not rule out the presence of an auxiliary HB, but the latter are usually rather weak due to geometric distortion. In a quantitative sense, the introduction of the various polar and H-bonding groups onto the aromatic systems raises the binding energy by a factor of 2-3 when compared to the naphthalene dimer, of roughly comparable size.

One can also compare the binding of TMZ to the nucleic acid bases to the strength of its interaction with other related molecules, all containing aromatic systems. First of all, the TMZ homodimer shows a distinct preference for a stacked geometry as compared to a coplanar HB structure, with binding energies of some 80 and $65 \mathrm{~kJ} / \mathrm{mol}$, respectively. ${ }^{33}$ A stacked geometry was also favored when TMZ was paired with chloroquine, ${ }^{34}$ although it must be understood that 
HBs were present even in a parallel arrangement, due in part to the flexibility of the chloroquine molecule. The parallel dimer is also preferred for the TMZ/quercetin dimer, ${ }^{35}$ which again allows intermolecular HBs in this arrangement.

Digesting these findings together with the results described here, there are two primary driving forces when the TMZ molecule interacts with another aromatic system. A stacked parallel arrangement is preferred for its high contribution of dispersion energy. But the formation of HBs is also a dominating influence, and the optimal arrangements usually involve the incorporation of both of these factors whenever possible. In cases like the nucleic acids, there is also the possibility of a stable perpendicular arrangement which permits the formation of a strong, undistorted HB, along with a greater amount of dispersion than can occur in a coplanar, purely HB structure.

Stacking between aromatic systems has been a subject of scrutiny for some time. Just recently for example, $\mathrm{Li}$ et $\mathrm{al}^{89}$ allowed benzene to interact with $\mathrm{C}_{60}$, and observed a preference for $\pi-\pi$ stacking over geometries which involve a $\mathrm{CH} \bullet \bullet \mathrm{H}$-bond. Like our own work above, their results pointed to dispersion as a dominant factor. With regard to nucleic acid bases, their interactions with aromatics such as acenaphthylene was recently examined by Trujillo and Goar Sanchez-Sanz ${ }^{90}$, who found stacked dimers with a preference for guanine over the other nucleobases. A combined experimental and computation effort ${ }^{91}$ designed and evaluated free energies of interaction between nucleobases and anthracene, again pointing to stacking interactions as a dominating force, even in aqueous solution. Auguring well for our own data above, these authors found good agreement between their experimental measurements and calculated data. Prior work has extended as well to radical cation dimers ${ }^{92-94}$ where both experimental and calculated data have shown that both stacked and perpendicular arrangements can occur in homo and heterodimers of aromatics. These geometries can at times be quite competitive in terms of energy, as for example in the case of the naphthalene/benzene dimer. This set of data also confirms our own findings that the introduction of polar and H-bonding groups can produce a dramatic increase in the binding energy.

\section{Acknowledgments}

O.E.K. would like to thank the Council for International Exchange of Scholars (CIES) for a Fulbright Visiting Scholar grant at Utah State University. Computer, storage and other resources 
from the Division of Research Computing in the Office of Research and Graduate Studies at Utah State University are gratefully acknowledged. 


\section{REFERENCES}

(1) Zhang, J; Stevens, M.FG.; Bradshaw, T.D. Temozolomide: Mechanisms of Action, Repair and Resistance. Current Molecular Pharmacology. 2012, 5, 102-114.

(2) Newlands, E.S.; Stevens, M.F.; Wedge, S.R.; Wheelhouse, R.T.; Brock, C. Temozolomide: a review of its discovery, chemical properties, pre-clinical development and clinical trial. Cancer Treat. Rev. 1997, 23, 35-61.

(3) Darkes, M.J.M.; Plosker, G.L.; Jarvis, B. Temozolomide. A review of its use in the treatment of malignant gliomas, malignant melanoma and other advanced cancers. Am. J. Cancer 2002, $1,55-80$.

(4) Hassani, S.M.; Bagheri, S.; Ghahremani, H. A theoretical study on the physicochemical and geometrical properties of the five anti-cancer drug using density functional theory for understanding their biological and anti-cancer activities. Ann. Biol. Res. 2012, 3, 2393-2398.

(5) Hvizdos, K.M.; Goa, K.L. Temozolomide. CNS Drugs 1999, 12, 237-243.

(6) Denny, B.J.; Wheelhouse, R.T.; Stevens, M.F. et al. NMR and molecular modeling investigation of the mechanism of activation of the antitumor drug temozolomide and its interaction with DNA. Biochemistry 1994, 33, 9045-9051.

(7) Stevens, M.F.; Hickman, J.A.; Langdon, S.P.; Chubb, D; Vickers, L.; Stone, R.; Baig, G.; Goddard, C.; Gibson, N.W.; Slack, J.A. et al. Antitumor activity and pharmacokinetics in mice of 8-carbamoyl-3-methyl-imidazo[5,1-d]-1,2,3,5- tetrazin-4(3H)-one (CCRG 81045; M \& B 39831), a novel drug with potential as an alternative to dacarbazine. Cancer Res. 1987, $47,5846-5852$.

(8) Friedman, H.S.; Kerby, T.; Calvert, H. Temozolomide and treatment of malignant glioma. Clin. Cancer Res. 2000, 6, 2285-2297.

(9) Ghobrial, I.M.; Witzig, T.E.; Adjei, A. Targeting apoptosis pathways in cancer therapy. CA Cancer J. Clin. 2005, 5, 178-194.

(10) "Central Brain Tumor Registry of the United States (CBTRUS) Report 2010," http://www.cbtrus.org/factsheet/factsheet.html.

(11) Stupp, R.; Mason, W.P.; Van Den Bent, M.J. et al. Radiotherapy plus concomitant and adjuvant temozolomide for glioblastoma. N. Eng. J. Med. 2005, 352, 987-996.

(12) DeAngelis, L. M. Brain tumors. N. Eng. J. Med. 2001, 344, 114-123.

(13) Laws, E.R.; Parney, I.F.; Huang, W. et al. Survival following surgery and prognostic factors for recently diagnosed malignant glioma: data from the glioma outcomes project. $J$. Neurosurg. 2003, 99, 467-473.

(14) Hobza, P.; Müller-Dethlefs, K. Non-covalent interactions: theory and experiment. Royal Society of Chemistry: Cambridge, UK, 2010.

(15) Karshikoff, A. Non-covalent interactions in proteins. World Scientific: London,2006.

(16) Scheiner, S. Noncovalent forces. Springer: Switzerland, 2015.

(17) Maharramov, A.M.; Mahmudov, K.T.; Kopylovich, M.N.; Pombeiro, A.J.L. Non-covalent interactions in the synthesis and design of new compounds. Wiley: New York, 2016.

(18) Lodish, H. Molecular cell biology, 4th edn. Freeman: New York, 2000

(19) Schuster, P.; Zundel, G.; Sandorfy, C. The hydrogen bond, recent developments in theory and experiments. North-Holland Publishing Co: Amsterdam,1976.

(20) Schuster, P. Hydrogen bonds. Springer: Berlin, 1984; p 120.

(21) Jeffrey, G.A.; Saenger, W. Hydrogen bonding in biological structures. Springer: Berlin, 1991.

(22) Scheiner, S. Hydrogen bonding: A theoretical perspective. Oxford University Press: New 
York, 1997; p 375.

(23) Gilli, G.; Gilli, P. The nature of the hydrogen bond. Oxford University Press: Oxford, 2009; p 313.

(24) Wieczorek, R; Dannenberg, J.J. H-bonding cooperativity and energetics of helix formation of five 17-amino acid peptides. J. Am. Chem. Soc. 2003, 125, 8124-8129.

(25) Alabugin, I.V.; Manoharan, M.; Peabody, S.; Weinhold, F. The electronic basis of improper hydrogen bonding: a subtle balance of hyperconjugation and rehybridization. J. Am. Chem. Soc. 2003, 125, 5973-5987.

(26) Hernández-Soto, H.; Weinhold, F.; Francisco, J.S. Radical hydrogen bonding: origin of stability of radical-molecule complexes. J. Chem. Phys. 2007, 127, 164102-164110.

(27) DelBene, J.E.; Alkorta, I.; Elguero. J. An ab initio study of cooperative effects in ternary complexes $\mathrm{X}$ : $\mathrm{CNH}: \mathrm{Z}$ with $\mathrm{X}, \mathrm{Z}=\mathrm{CNH}, \mathrm{FH}, \mathrm{ClH}, \mathrm{FCl}$, and $\mathrm{HLi}$ : structures, binding energies, and spin-spin coupling constants across intermolecular bonds. Phys. Chem. Chem. Phys. 2011, 13, 13951-13961.

(28) Thakur, T.S.; Kirchner, M.T.; Blaser, D.; Boese, R.; Desiraju, G.R. Nature and strength of $\mathrm{C}-\mathrm{H}$...O interactions involving formyl hydrogen atoms: computational and experimental studies of small aldehydes. Phys. Chem. Chem. Phys. 2011, 13, 14076-14091.

(29) Lee, C.T.; Yang, W.; Parr, R.G. Development of the Colle-Salvetti correlation-energy formula into a functional of the electron density. Phys. Rev. 1988, B37, 785-789.

(30) Kasende, O.E.; Matondo, A.; Muzomwe, M.; Muya, J.T.; Scheiner, S. Interaction between temozolomide and water: preferred binding sites. Comput. Theor. Chem. 2014, 1034, 26-29.

(31) Kasende, O.E.; Muya, J.T.; Scheiner, S.; Regioselectivity of the interaction of temozolomide with borane and boron trifluoride. Struct. Chem. 2015, 11234, 640-646.

(32) Kasende, O.E.; Matondo, A.; Muya, J.T.; Scheiner, S.; Interaction between temozolomide and water: preferred binding sites. Comput. Theor. Chem. 2016, 1075, 82-26.

(33) Kasende, O.E.; Muya, J.T.; Nziko, V.de P.; Scheiner, S. Hydrogen bonded and stacked geometries of the temozolomide dimer. J. Mol. Mod. 2016, 22, 1-9

(34) Kasende, O.E.; Nziko, V. de P.; Scheiner, S. H-Bonding and Stacking Interactions between Chloroquine and Temozolomide. Int. J. Quant. Chem. 2016, 116, 1196-1204

(35) Kasende, O.E.; Nziko, V.de P.; Scheiner, S.; Interactions between Temozolomide and Quercetin. Struct. Chem. DOI: 10.1007/s11224-016-0788-8

(36) Tomic, K.; Tatchen, J.; Marian, C.M. Quantum chemical investigation of the electronic spectra of the keto, enol, and keto-imine tautomers of cytosine. J. Phys. Chem. A, 2005, 109 , $8410-8418$.

(37) Trygubenko, S.A.; Bogdan, T.V.; Rueda, M.; Orozco, M.; Luque, F.J.; Sponer, J.; Slavicek, P.; Hobza, P. Correlated ab initio study of nucleic acid bases and their tautomers in the gas phase, in a microhydrated environment and in aqueous solution-Part 1. Cytosine. Phys. Chem. Chem. Phys. 2002, 4, 4192 - 4203.

(38) Kobayashi, R. A CCSD (T) study of the relative stabilities of cytosine tautomers. J. Phys. Chem. A 1998, 102, 10813-10817.

(39) Szczesniak, M.; Szczepaniak, K.; Kwiatkowski, J.S.; Kubulat, K.; Person, W.B. Matrixisolation infrared studies of nucleic-acid constituents. 5. Experimental matrix- isolation and theoretical ab initio SCF molecular-orbital studies of the infrared spectra of cytosine monomers. J. Am. Chem. Soc. 1988, 110, 8319-8330.

(40) Becker, R. S.; Kogan, G. Photophysical properties of nucleic acid components 1. The pyrimidines: thymine, uracil, N,N-dimethyl derivatives and thymidine. Photochem. 
Photobiol. 1980, 31, 5-13.

(41) Nowak, M.J.; Szczepaniak, K.; Barski, A.; and Shugar, D. Spectroscopic studies on vaporphase tautomerism of natural bases found in nucleic-acids. Z. Naturforsch. C 1978, 33, 876883.

(42) Brown, R.D.; Godfrey, P.D.; McNaughton, D.; Pierlot, A. The microwave spectrum of uracil. J. Am. Chem. Soc., 1988, 110, 2329-2330.

(43) Viant, M.R.; Fellers, R.S.; Mclaughlin, R.P.; and Saykally, R.J. Infrared-laser spectroscopy of uracil in a pulsed slit jet. J. Chem. Phys., 1995, 103, 9502-9505.

(44) Brown, R.D.; Godfrey, P.D.; Mcnaughton, D.; Pierlot, A.P. Microwave-spectrum of the major gas-phase tautomer of thymine. J. Chem. Soc., Chem. Commun., 1989, 1, 37-38.

(45) Leszczynski, J. In Encyclopedia of Computational Chemistry; Schleyer ,P. v. R. Ed.; John Wiley: Chichester, 1998; 2951.

(46) Szczepaniak, K.; Szczesniak, M. Matrix-isolation infrared studies of nucleic acid constituents. 4. Guanine and 9-methylguanine monomers and their keto-enol-tautomerism. $J$. Mol. Struct. 1987, 156, 29-42.

(47) Dolgounitcheva, O.; Zakrzewski, V.G.; Ortiz, J.V. Electron propagator theory of guanine and its cations: Tautomerism and photoelectron spectra. J. Am. Chem. Soc. 2000, 122, 1230412309.

(48) Leszczynski, J. The Potential Energy Surface of Guanine Is Not Flat: An ab Initio Study with Large Basis Sets and Higher Order Electron Correlation Contributions. J. Phys. Chem. A 1998, 102, 2357-2362.

(49) Colominas, C.; Luque, F. J.; Orozco, M. Tautomerism and Protonation of Guanine and Cytosine. Implications in the Formation of Hydrogen-Bonded Complexes. J. Am. Chem. Soc. 1996, 118, 6811-6821.

(50) Sabio, M.; Topiol, S.; Lumma, W.C. An investigation of tautomerism in adenine and guanine. J. Phys. Chem. 1990, 94, 1366-1372

(51) Szczepaniak, K.; Szczepaniak, M.; Szaida, W.; Person, W. B.; Leszczynski, J. Infrared spectra of tautomers and rotamers of 9-methylguanine. An experimental and theoretical study. Can. J. Chem. 1991, 69, 1705-1720.

(52) Plutzer, C.; Kleinermanns, K. Tautomers and electronic states of jet- cooled adenine investigated by double resonance spectroscopy. Phys. Chem. Chem. Phys. 2002, 4, 4877-4882.

(53) Plutzer, C.; Nir, E.; de Vries, M.S.; Kleinermanns, K. IR-UV double-resonance spectroscopy of the nucleobase adenine. Phys. Chem. Chem. Phys., 2001, 3, 5466-5469.

(54) Becke, A.D. Density-functional thermochemistry. III. The role of exact exchange. J. Chem. Phys. 1993, 98, 5648-5662.

(55) Grimme, S. Density functional theory with London dispersion corrections. WIREs Computational Molecular Science John Wiley \& Sons Ltd 2011, 211-228.

(56) Zhao, Y.; Truhlar, D.G. The M06 suite of density functionals for main group thermochemistry, thermochemical kinetics, noncovalent interactions, excited states, and transition elements: two new functionals and systematic testing of four M06-class functionals and 12 other functionals. Theor. Chem. Account 2008, 120, 215-241.

(57) Walker, M; Harvey, A.J.A.; Sen, A.; Dessent, C.E.H. Performance of M06, M06-2X, and M06-HF Density Functionals for Conformationally Flexible Anionic Clusters: M06 Functionals Perform Better than B3LYP for a Model System with Dispersion and Ionic Hydrogen-Bonding Interactions. J. Phys. Chem. A 2013, 117, 12590-12600.

(58) Cohen, A.J., Mori-Sánchez, P.; Yang, W. Challenges for Density Functional Theory. Chemical Reviews, 2012, 112, 289-320. 
(59) Hohenstein, E.G.; Chill S.T.; Sherrill, C.D. Assessment of the Performance of the M05-2X and M06-2X Exchange-Correlation Functionals for Noncovalent Interactions in Biomolecules. J. Chem. Theor. Comput. 2008, 4, 1996-2000.

(60) Riley, K.E.; Pitoňák, M.; Jurečka, P.; Hobza, P. Stabilization and Structure Calculations for Noncovalent Interactions in Extended Molecular Systems Based on Wave Function and Density Functional Theories. Chem. Rev. 2010, 110, 5023-63.

(61) Ferrighi, L.; Pan, Y.; Grönbeck, H.; Hammer, B. Stabilization and Structure Calculations for Noncovalent Interactions in Extended Molecular Systems Based on Wave Function and Density Functional Theories. J. Phys. Chem. 2012, 116, 7374-7379.

(62) Chai, J.D.; Head, M. Long-range corrected hybrid density functional with damped atomatom dispersion corrections. Phys. Chem. Chem. Phys. 2008, 10, 6615-6620.

(63) DiLabio, G.A.; Johnson, E.R.; Otero-de-la-Roza, A. Performance of conventional and dispersion-corrected density-functional theory methods for hydrogen bonding interaction energies. Phys. Chem. Chem. Phys. 2013, 15, 12821-12828.

(64) Gutowski, M.; van Duijneveldt van de Rijdt, J.G.C.M.; van Lenthe, J.H.; van Duijneveldt, F.B. Accuracy of the boys and bernardi function counterpoise method. J. Chem. Phys. 1993, 98, 4728-4738.

(65) Boys, S.F.; Bernardi, F. The calculation of small molecular interactions by thedifference of separate total energies. Some procedures with reduced errors. Mol. Phys. 1970, 19, 553-566.

(66) Grimme, S.; Antony, J.; Ehrlich, S.; Krieg, H.; A consistent and accurate ab initio parametrization of density functional dispersion correction (DFT-D) for the 94 elements HPu. J. Chem. Phys. 2010, 132, 154104 -154119.

(67) Grimme, S.; Ehrlich, S.; Goerigk, L. Effect of the damping function in dispersion corrected density functional theory. J. Comput. Chem. 2011, 32, 1456-1465.

(68) Becke A.D.; Johnson, E.R. Exchange-hole dipole moment and the dispersion interaction. $J$. Chem. Phys. 2005, 122, 154104-154105.

(69) Johnson, E.R.; Becke, A.D. A density-functional model of the dispersion interaction. $J$. Chem. Phys. 2005, 123, 024101-9.

(70) Axilrod, B.M.; Teller, E. "Interaction of the van der Waals Type Between Three Atoms. J. Chem. Phys. 1943, 11, 299-300.

(71) Mutto, J. Force between non-polar molecules. Proc. Phys. Math. Soc. Japan 1943, 17, 629631.

(72) Grimme, S. grimme_dftd3.3.0.2. Available at: http://www.thch.unibonn. de/

(73) Frisch, M.J.; Trucks, G.W.; Schlegel, H.B.; Scuseria, G.E.; Robb, M.A.; Cheeseman, J.R.; Scalmani, G.; Barone, V.; Mennucci, B.; Petersson, G.A. et al. Gaussian 09, revision A.02, Gaussian Inc., Wallingford, CT 2009.

(74) Glendening, E.D.; Badenhoop, J.K.; Reed, A.E.; Carpenter, J.E.; Bohmann, J.A.; Morales, C.M.; Landis, C.R.; Weinhold, F. NBO 6.0. Theoretical Chemistry Institute, University of Wisconsin, Madison 2013.

(75) Dennington, R.; Keith, T.; Millan, J. GaussView, version 5, Semichem. Inc., Shawnee Mission, KS 2009.

(76) Mennucci, B.; Tomasi, J.; Cammi, R.; Cheeseman, J.R.; Frisch, M.J.; Devlin F.J.; Gabriel, S.; Stephens, P.J. Polarizable Continuum Model (PCM) Calculations of Solvent Effects on Optical Rotations of Chiral Molecules. J. Phys. Chem. A, 2002, 106, 6102-6113

(77) Mennucci, B. Polarizable continuum model. WIREs Comput. Mol. Sci 2012, 2, 386-404

(78) Tomasi, J.; Mennucci, B.; Cammi, R. Quantum Mechanical Continuum Solvation Models. 
Chem. Rev. 2005, 105, 2999-3094.

(79) Tsuzuki, S.; Uchimaru, T.; Matsumura, K.; Mikami, M.; Tanabe, K. Effects of the higher electron correlation correction on the calculated intermolecular interaction energies of benzene and naphthalene dimers: comparison between MP2 and CCSD(T) calculations. Chem. Phys. Lett. 2000, 319, 547-554.

(80) Simonson, T.; Perahia, D. Internal and interfacial dielectric properties of cytochrome c from molecular dynamics. Proc. Nat. Acad. Sci., USA 1995, 92, 1082-1086.

(81) Dwyer, J. J.; Gittis, A. G.; Karp, D. A.; Lattman, E. E.; Spencer, D. S.; Stites, W. E.; Garcia-Moreno, B. High apparent dielectric constants in the interior of a protein reflect water penetration. Biophys. J. 2000, 79, 1610-1620.

(82) Scheiner, S.; Kar, T. Effect of solvent upon $\mathrm{CH} \cdot \mathrm{O}$ hydrogen bonds with implications for protein folding. J. Phys. Chem. B 2005, 109, 3681-3689.

(83) Li, L.; Li, C.; Zhang, Z.; Alexov, E. On the dielectric "constant" of proteins: Smooth dielectric function for macromolecular modeling and its implementation in DelPhi. J. Chem. Theory Comput. 2013, 9, 2126-2136.

(84) Sahakyan, A. B. Computational studies of dielectric permittivity effects on chemical shifts of alanine dipeptide. Chem. Phys. Lett. 2012, 547, 66-72.

(85) Wang, Z.-X.; Duan, Y. Solvation effects on alanine dipeptide: A MP2/cc-pVTZ//MP2/6$31 \mathrm{G}^{* *}$ study of $(\Phi, \Psi)$ energy maps and conformers in the gas phase, ether, and water. $J$. Comput. Chem. 2004, 25, 1699-1716.

(86) Schutz, C. N.; Warshel, A. What are the dielectric constants of proteins and how to validate electrostatic models? Proteins Struct. Func. Genetics 2001, 44, 400-417.

(87) Lee, N. K.; Park, S.; Kim, S. K. Ab initio studies on the van der Waals complexes of polycyclic aromatic hydrocarbons. II. Naphthalene dimer and naphthalene-anthracene complex. J. Chem. Phys. 2002, 116, 7910-7917.

(88) Dubinets, N. O.; Safonov, A. A.; Bagaturyants, A. A. Structures and Binding Energies of the Naphthalene Dimer in Its Ground and Excited States. J. Phys. Chem. A 2016, 120, 27792782.

(89) Li, M.-M.; Wang, Y.-B.; Zhang, Y.; Wang, W. The Nature of the Noncovalent Interactions between Benzene and $\mathrm{C}_{60}$ Fullerene. J. Phys. Chem. A 2016, 120, 5766-5772.

(90) Trujillo, C.; Sánchez-Sanz, G. A Study of П-П Stacking Interactions and Aromaticity in Polycyclic Aromatic Hydrocarbon/Nucleobase Complexes. ChemPhysChem. 2016, 17, 395405.

(91). Kataev, E. A.; Shumilova, T. A.; Fiedler, B.; Anacker, T.; Friedrich, J. Understanding Stacking Interactions between an Aromatic Ring and Nucleobases in Aqueous Solution: Experimental and Theoretical Study. J. Org. Chem. 2016, 81, 6505-6514.

(92) Platt, S. P.; Attah, I. K.; Aziz, S.; El-Shall, M. S. Communication: Ion Mobility of the Radical Cation Dimers: (Naphthalene)2+• and Naphthalene+•-Benzene: Evidence for Stacked Sandwich and T-Shape Structures. J. Chem. Phys. 2015, 142, 191102.

(93) Attah, I. K.; Platt, S. P.; Meot-Ner, M.; El-Shall, M. S.; Peverati, R.; Head-Gordon, M. What Is the Structure of the Naphthalene-Benzene Heterodimer Radical Cation? Binding Energy, Charge Delocalization, and Unexpected Charge-Transfer Interaction in Stacked Dimer and Trimer Radical Cations. J. Phys. Chem. Lett. 2015, 6, 1111-1118.

(94) Attah, I. K.; Platt, S. P.; Meot-Ner , M.; El-Shall, M. S.; Aziz, S. G.; Alyoubi, A. O. ProtonBound Dimers of Nitrogen Heterocyclic Molecules: Substituent Effects on the Structures 
and Binding Energies of Homodimers of Diazine, Triazine, and Fluoropyridine. J. Chem. Phys. 2014, 140, 114313. 
Table 1. Binding energies BE and NBO second-order perturbation energy E(2) of uracil -TMZ dimers. HB, P, S1, or S2 designations refer to category of structure, see text.

\begin{tabular}{|c|c|c|c|c|c|c|}
\hline Dimer & \multicolumn{4}{|c|}{$\mathrm{BE}(\mathrm{kJ} / \mathrm{mol})$} & \multirow[b]{2}{*}{ TMZ...uracil } & \multirow{2}{*}{$\begin{array}{c}\mathrm{NBO} \\
\mathrm{E}(2) \\
(\mathrm{kJ} / \mathrm{mol})\end{array}$} \\
\hline & M06-2X & $\begin{array}{l}\omega \mathrm{B} 97- \\
\mathrm{XD}\end{array}$ & $\begin{array}{l}\text { B3LYP- } \\
\text { D3 }\end{array}$ & MP2 & & \\
\hline $\begin{array}{l}\mathrm{U} 1 \\
\mathrm{HB}\end{array}$ & -70.94 & -74.86 & -74.50 & -51.79 & $\begin{array}{l}\mathrm{O}_{2}(\mathrm{LPs}) \rightarrow \mathrm{N}_{7}-\mathrm{H}_{7}\left(\sigma^{*}\right) \\
\mathrm{N}_{6}-\mathrm{H}_{4}\left(\sigma^{*}\right) \leftarrow \mathrm{O}_{3}(\mathrm{LPs})\end{array}$ & $\begin{array}{l}138.24 \\
72.43\end{array}$ \\
\hline $\begin{array}{l}\mathrm{U} 2 \\
\mathrm{P}\end{array}$ & -68.82 & -62.92 & -62.67 & -47.55 & $\begin{array}{l}\mathrm{O}_{2}(\mathrm{LPs}) \rightarrow \mathrm{N}_{7}-\mathrm{H}_{7}\left(\sigma^{*}\right) \\
\mathrm{N}_{3}(\mathrm{LP}) \rightarrow \mathrm{N}_{7}-\mathrm{H}_{7}\left(\sigma^{*}\right) \\
\mathrm{C}_{1}-\mathrm{C}_{4}\left(\pi^{*}\right) \leftarrow \mathrm{O}_{3}(\mathrm{LPs}) \\
\mathrm{N}_{2}-\mathrm{N}_{3}(\pi) \rightarrow \mathrm{N}_{7}-\mathrm{H}_{7}\left(\sigma^{*}\right) \\
\mathrm{C}_{6}-\mathrm{O}_{2}(\pi) \rightarrow \mathrm{N}_{7}-\mathrm{H}_{7}\left(\sigma^{*}\right)\end{array}$ & $\begin{array}{l}25.48 \\
12.43 \\
3.77 \\
2.64 \\
2.34 \\
\end{array}$ \\
\hline $\begin{array}{l}\text { U3 } \\
\text { S1 }\end{array}$ & -60.81 & -55.95 & -55.12 & -41.71 & $\begin{array}{l}\mathrm{O}_{2}(\mathrm{LPs}) \rightarrow \mathrm{N}_{7}-\mathrm{H}_{7}\left(\sigma^{*}\right) \\
\mathrm{C}_{6}-\mathrm{O}_{2}(\pi) \rightarrow \mathrm{N}_{7}-\mathrm{H}_{7}\left(\sigma^{*}\right) \\
\mathrm{C}_{3}-\mathrm{H}_{3}\left(\sigma^{*}\right) \leftarrow \mathrm{O}_{4}(\mathrm{LPs}) \\
\mathrm{N}_{2}-\mathrm{N}_{3}\left(\pi^{*}\right) \leftarrow \mathrm{N}_{7}(\mathrm{LP})\end{array}$ & $\begin{array}{l}32.38 \\
12.22 \\
3.01 \\
2.68 \\
\end{array}$ \\
\hline $\begin{array}{l}\text { U4 } \\
\text { S2 }\end{array}$ & -60.72 & -52.65 & -47.95 & -36.33 & $\begin{array}{l}\mathrm{C}_{1}-\mathrm{C}_{4}(\pi) \rightarrow \mathrm{O}_{3}-\mathrm{C}_{7}\left(\pi^{*}\right) \\
\mathrm{C}_{6}-\mathrm{O}_{2}(\pi) \rightarrow \mathrm{C}_{8}-\mathrm{C}_{9}\left(\pi^{*}\right) \\
\mathrm{C}_{6}-\mathrm{O}_{2}(\pi) \leftarrow \mathrm{C}_{8}-\mathrm{C}_{9}\left(\pi^{*}\right) \\
\mathrm{C}_{1}-\mathrm{C}_{4}\left(\pi^{*}\right) \leftarrow \mathrm{O}_{3}-\mathrm{C}_{7}(\pi) \\
\mathrm{C}_{2}-\mathrm{O}_{1}\left(\pi^{*}\right) \leftarrow \mathrm{O}_{3}-\mathrm{C}_{7}(\pi)\end{array}$ & $\begin{array}{l}5.14 \\
4.64 \\
2.51 \\
2.34 \\
2.05\end{array}$ \\
\hline $\begin{array}{l}\text { U5 } \\
\text { HB }\end{array}$ & -53.28 & -56.10 & -55.91 & -34.49 & $\begin{array}{l}\mathrm{O}_{2}(\mathrm{LPs}) \rightarrow \mathrm{N}_{8}-\mathrm{H}_{10}\left(\sigma^{*}\right) \\
\mathrm{N}_{6}-\mathrm{H}_{4}\left(\sigma^{*}\right) \leftarrow \mathrm{O}_{4}(\mathrm{LPs})\end{array}$ & $\begin{array}{l}105.52 \\
69.41 \\
\end{array}$ \\
\hline $\begin{array}{l}\text { U6 } \\
\text { HB }\end{array}$ & -50.59 & -52.68 & -52.23 & -32.09 & $\begin{array}{l}\mathrm{O}_{2}(\mathrm{LPs}) \rightarrow \mathrm{N}_{8}-\mathrm{H}_{10}\left(\sigma^{*}\right) \\
\mathrm{N}_{6}-\mathrm{H}_{4}\left(\sigma^{*}\right) \leftarrow \mathrm{O}_{3}(L P)\end{array}$ & $\begin{array}{l}98.53 \\
69.71\end{array}$ \\
\hline $\begin{array}{l}\text { U7 } \\
\text { S1 }\end{array}$ & -49.44 & -44.22 & -39.10 & -26.76 & $\begin{array}{l}\mathrm{C}_{3}-\mathrm{H}_{2}\left(\sigma^{*}\right) \leftarrow \mathrm{O}_{4}(\mathrm{LPs}) \\
\mathrm{C}_{1}-\mathrm{C}_{4}(\pi) \rightarrow \mathrm{C}_{8}-\mathrm{C}_{9}\left(\pi^{*}\right) \\
\mathrm{C}_{3}-\mathrm{H}_{2}\left(\sigma^{*}\right) \leftarrow \mathrm{C}_{10}-\mathrm{O}_{4}(\pi) \\
\mathrm{C}_{5}-\mathrm{N}_{5}\left(\pi^{*}\right) \leftarrow \mathrm{O}_{3}-\mathrm{C}_{7}(\pi) \\
\mathrm{C}_{1}-\mathrm{C}_{4}\left(\pi^{*}\right) \leftarrow \mathrm{C}_{8}-\mathrm{C}_{9}(\pi) \\
\mathrm{N}_{4}(\mathrm{LP}) \rightarrow \mathrm{O}_{3}-\mathrm{C}_{7}\left(\pi^{*}\right)\end{array}$ & $\begin{array}{l}5.73 \\
4.31 \\
3.85 \\
3.39 \\
2.89 \\
2.43 \\
\end{array}$ \\
\hline $\begin{array}{l}\text { U8 } \\
\text { HB }\end{array}$ & -48.97 & -53.62 & -54.08 & -31.62 & $\begin{array}{l}\mathrm{N}_{5}(\mathrm{LP}) \rightarrow \mathrm{N}_{8}-\mathrm{H}_{10}\left(\sigma^{*}\right) \\
\mathrm{N}_{6}-\mathrm{H}_{5}\left(\sigma^{*}\right) \leftarrow \mathrm{O}_{4}(\mathrm{LPs}) \\
\mathrm{C}_{5}-\mathrm{H}_{6}\left(\sigma^{*}\right) \leftarrow \mathrm{O}_{3}(\mathrm{LPs})\end{array}$ & $\begin{array}{l}107.03 \\
43.72 \\
12.34 \\
\end{array}$ \\
\hline $\begin{array}{l}\text { U9 } \\
\text { HB }\end{array}$ & -48.51 & -52.74 & -53.19 & -30.88 & $\begin{array}{l}\mathrm{N}_{5}(\mathrm{LP}) \rightarrow \mathrm{N}_{8}-\mathrm{H}_{10}\left(\sigma^{*}\right) \\
\mathrm{N}_{6}-\mathrm{H}_{5}\left(\sigma^{*}\right) \leftarrow \mathrm{O}_{3}(\mathrm{LPs}) \\
\mathrm{C}_{5}-\mathrm{H}_{6}\left(\sigma^{*}\right) \leftarrow \mathrm{O}_{4}(\mathrm{LPs})\end{array}$ & $\begin{array}{l}107.03 \\
39.87 \\
13.22 \\
\end{array}$ \\
\hline $\begin{array}{l}\text { U10 } \\
\text { HB }\end{array}$ & -39.98 & -42.59 & -43.12 & -24.21 & $\begin{array}{l}\mathrm{O}_{1}(\mathrm{LPs}) \rightarrow \mathrm{N}_{7}-\mathrm{H}_{7}\left(\sigma^{*}\right) \\
\mathrm{C}_{5}-\mathrm{H}_{6}\left(\sigma^{*}\right) \leftarrow \mathrm{O}_{3}(\mathrm{LPs})\end{array}$ & $\begin{array}{l}66.02 \\
41.80\end{array}$ \\
\hline $\begin{array}{l}\text { U11 } \\
\text { HB }\end{array}$ & -34.52 & -36.01 & -36.31 & -18.62 & $\begin{array}{l}\mathrm{O}_{1}(\mathrm{LPs}) \rightarrow \mathrm{N}_{8}-\mathrm{H}_{10}\left(\sigma^{*}\right) \\
\mathrm{C}_{5}-\mathrm{H}_{6}\left(\sigma^{*}\right) \leftarrow \mathrm{O}_{4}(\mathrm{LPs})\end{array}$ & $\begin{array}{l}12.92 \\
8.97\end{array}$ \\
\hline $\begin{array}{l}\text { U12 } \\
\text { HB }\end{array}$ & -33.48 & -34.65 & -34.63 & -17.63 & $\begin{array}{l}\mathrm{O}_{1}(\mathrm{LPs}) \rightarrow \mathrm{N}_{8}-\mathrm{H}_{10}\left(\sigma^{*}\right) \\
\mathrm{C}_{5}-\mathrm{H}_{6}\left(\sigma^{*}\right) \leftarrow \mathrm{O}_{3}(\mathrm{LPs})\end{array}$ & $\begin{array}{l}13.39 \\
9.24 \\
\end{array}$ \\
\hline
\end{tabular}


Table 2. Binding energies BE and NBO second-order perturbation energy E(2) of thymine -TMZ dimers

\begin{tabular}{|c|c|c|c|c|c|c|}
\hline Dimer & \multicolumn{4}{|c|}{$\mathrm{BE}(\mathrm{kJ} / \mathrm{mol})$} & \multirow[b]{2}{*}{ TMZ-thymine } & \multirow{2}{*}{$\begin{array}{l}\mathrm{NBO} \mathrm{E}(2) \\
(\mathrm{kJ} / \mathrm{mol})\end{array}$} \\
\hline & M06-2X & $\begin{array}{l}\omega B 97- \\
\text { XD }\end{array}$ & $\begin{array}{l}\text { B3LYP- } \\
\text { D3 }\end{array}$ & MP2 & & \\
\hline $\begin{array}{l}\text { T1 } \\
\mathrm{HB}\end{array}$ & -70.09 & -73.80 & -73.78 & -51.33 & $\begin{array}{l}\mathrm{O}_{2}(\mathrm{LPs}) \rightarrow \mathrm{N}_{7}-\mathrm{H}_{7}\left(\sigma^{*}\right) \\
\mathrm{N}_{6}-\mathrm{H}_{4}\left(\sigma^{*}\right) \leftarrow \mathrm{O}_{3}(\mathrm{LPs})\end{array}$ & $\begin{array}{l}131.71 \\
76.61\end{array}$ \\
\hline $\begin{array}{l}\text { T2 } \\
P\end{array}$ & -67.96 & -62.29 & -62.02 & -47.40 & $\begin{array}{l}\mathrm{O}_{2}(\mathrm{LPs}) \rightarrow \mathrm{N}_{7}-\mathrm{H}_{7}\left(\sigma^{*}\right) \\
\mathrm{N}_{3}(\mathrm{LP}) \rightarrow \mathrm{N}_{7}-\mathrm{H}_{7}\left(\sigma^{*}\right) \\
\mathrm{C}_{1}-\mathrm{C}_{4}\left(\pi^{*}\right) \leftarrow \mathrm{O}_{3}(\mathrm{LPs}) \\
\mathrm{C}_{6}-\mathrm{O}_{2}(\pi) \rightarrow \mathrm{N}_{7}-\mathrm{H}_{7}\left(\sigma^{*}\right) \\
\mathrm{N}_{2}-\mathrm{N}_{3}(\pi) \rightarrow \mathrm{N}_{7}-\mathrm{H}_{7}\left(\sigma^{*}\right)\end{array}$ & $\begin{array}{l}26.48 \\
12.25 \\
4.02 \\
2.64 \\
2.47 \\
\end{array}$ \\
\hline $\begin{array}{l}\text { T3 } \\
\text { S1 }\end{array}$ & -61.19 & -56.23 & -55.44 & -42.72 & $\begin{array}{l}\mathrm{O}_{2}(\mathrm{LPs}) \rightarrow \mathrm{N}_{7}-\mathrm{H}_{7}\left(\sigma^{*}\right) \\
\mathrm{C}_{6}-\mathrm{O}_{2}(\pi) \rightarrow \mathrm{N}_{7}-\mathrm{H}_{7}\left(\sigma^{*}\right) \\
\mathrm{N}_{2}-\mathrm{N}_{3}\left(\pi^{*}\right) \leftarrow \mathrm{N}_{7}(\mathrm{LP}) \\
\mathrm{C}_{3}-\mathrm{H}_{2}\left(\pi^{*}\right) \leftarrow \mathrm{O}_{4}(\mathrm{LPs})\end{array}$ & $\begin{array}{l}26.86 \\
11.59 \\
2.26 \\
2.26 \\
\end{array}$ \\
\hline $\begin{array}{l}\mathrm{T} 4 \\
\mathrm{~S} 2\end{array}$ & -58.21 & -48.88 & -44.91 & -33.94 & $\begin{array}{l}\mathrm{C}_{6}-\mathrm{O}_{2}\left(\pi^{*}\right) \leftarrow \mathrm{N}_{7}(\mathrm{LP}) \\
\mathrm{C}_{1}-\mathrm{C}_{4}(\pi) \rightarrow \mathrm{C}_{11}-\mathrm{O}_{4}\left(\pi^{*}\right) \\
\mathrm{N}_{2}(\mathrm{LP}) \rightarrow \mathrm{C}_{7}-\mathrm{H}_{10}\left(\sigma^{*}\right) \\
\mathrm{C}_{6}-\mathrm{O}_{2}(\pi) \rightarrow \mathrm{C}_{8}-\mathrm{C}_{9}\left(\pi^{*}\right) \\
\mathrm{C}_{2}-\mathrm{O}_{1}\left(\pi^{*}\right) \leftarrow \mathrm{C}_{11}-\mathrm{O}_{4}(\pi) \\
\mathrm{N}_{2}-\mathrm{N}_{3}(\pi) \rightarrow \mathrm{C}_{7}-\mathrm{H}_{10}\left(\sigma^{*}\right) \\
\mathrm{C}_{1}-\mathrm{C}_{4}(\pi) \rightarrow \mathrm{C}_{10}-\mathrm{O}_{3}\left(\pi^{*}\right)\end{array}$ & $\begin{array}{l}5.73 \\
3.56 \\
3.26 \\
2.76 \\
2.43 \\
2.30 \\
2.22 \\
\end{array}$ \\
\hline $\begin{array}{l}\text { T5 } \\
\text { S1 }\end{array}$ & -55.90 & -52.91 & -49.74 & -36.38 & $\begin{array}{l}\mathrm{O}_{2}(\mathrm{LPs}) \rightarrow \mathrm{N}_{7}-\mathrm{H}_{7}\left(\sigma^{*}\right) \\
\mathrm{C}_{3}-\mathrm{H}_{2}\left(\sigma^{*}\right) \leftarrow \mathrm{O}_{4}(\mathrm{LPs}) \\
\mathrm{C}_{1}-\mathrm{C}_{4}\left(\pi^{*}\right) \leftarrow \mathrm{C}_{8}-\mathrm{C}_{9}(\pi) \\
\mathrm{C}_{1}-\mathrm{C}_{4}(\pi) \rightarrow \mathrm{C}_{8}-\mathrm{C}_{9}\left(\pi^{*}\right) \\
\mathrm{C}_{3}-\mathrm{H}_{2}\left(\sigma^{*}\right) \leftarrow \mathrm{C}_{11}-\mathrm{O}_{4}(\pi)\end{array}$ & $\begin{array}{l}19.03 \\
3.47 \\
3.31 \\
2.05 \\
1.97\end{array}$ \\
\hline $\begin{array}{l}\text { T6 } \\
\text { S1 }\end{array}$ & -55.83 & -52.33 & -46.56 & -34.71 & $\begin{array}{l}\mathrm{C}_{3}-\mathrm{H}_{3}\left(\sigma^{*}\right) \leftarrow \mathrm{O}_{3}(\mathrm{LPs}) \\
\mathrm{N}_{5}(\mathrm{LP}) \rightarrow \mathrm{C}_{7}-\mathrm{H}_{9}\left(\sigma^{*}\right) \\
\mathrm{C}_{3}-\mathrm{H}_{3}\left(\sigma^{*}\right) \leftarrow \mathrm{C}_{10}-\mathrm{O}_{3}(\pi)\end{array}$ & $\begin{array}{l}5.69 \\
2.89 \\
2.59 \\
\end{array}$ \\
\hline $\begin{array}{l}\text { T7 } \\
\text { HB }\end{array}$ & -52.27 & -55.15 & -54.87 & -33.57 & $\begin{array}{l}\mathrm{O}_{2}(\mathrm{LPs}) \rightarrow \mathrm{N}_{8}-\mathrm{H}_{8}\left(\sigma^{*}\right) \\
\mathrm{N}_{6}-\mathrm{H}_{4}\left(\sigma^{*}\right) \leftarrow \mathrm{O}_{4}(\mathrm{LPs})\end{array}$ & $\begin{array}{l}101.09 \\
70.37 \\
\end{array}$ \\
\hline $\begin{array}{l}\text { T8 } \\
\text { HB }\end{array}$ & -51.14 & -52.96 & -52.82 & -32.38 & $\begin{array}{l}\mathrm{O}_{2}(\mathrm{LPs}) \rightarrow \mathrm{N}_{8}-\mathrm{H}_{8}\left(\sigma^{*}\right) \\
\mathrm{N}_{6}-\mathrm{H}_{4}\left(\pi^{*}\right) \leftarrow \mathrm{O}_{3}(\mathrm{LPs})\end{array}$ & $\begin{array}{l}167.95 \\
70.46 \\
\end{array}$ \\
\hline $\begin{array}{l}\text { T9 } \\
\text { HB }\end{array}$ & -49.16 & -53.80 & -54.45 & -31.76 & $\begin{array}{l}\mathrm{N}_{5}(\mathrm{LP}) \rightarrow \mathrm{N}_{8}-\mathrm{H}_{8}\left(\sigma^{*}\right) \\
\mathrm{N}_{6}-\mathrm{H}_{5}\left(\sigma^{*}\right) \leftarrow \mathrm{O}_{4}(\mathrm{LPs}) \\
\mathrm{C}_{5}-\mathrm{H}_{6}\left(\sigma^{*}\right) \leftarrow \mathrm{O}_{3}(\mathrm{LPs})\end{array}$ & $\begin{array}{l}108.65 \\
41.09 \\
13.85 \\
\end{array}$ \\
\hline $\begin{array}{l}\text { T10 } \\
\text { HB }\end{array}$ & -48.81 & -52.93 & -53.73 & -31.24 & $\begin{array}{l}\mathrm{N}_{5}(\mathrm{LP}) \rightarrow \mathrm{N}_{8}-\mathrm{H}_{8}\left(\sigma^{*}\right) \\
\mathrm{N}_{6}-\mathrm{H}_{5}\left(\sigma^{*}\right) \leftarrow \mathrm{O}_{3}(\mathrm{LPs}) \\
\mathrm{C}_{5}-\mathrm{H}_{6}\left(\sigma^{*}\right) \leftarrow \mathrm{O}_{4}(\mathrm{LPs})\end{array}$ & $\begin{array}{l}214.35 \\
66.15 \\
30.50 \\
\end{array}$ \\
\hline $\begin{array}{l}\text { T11 } \\
\text { S1 }\end{array}$ & -47.49 & -40.03 & -37.39 & -25.86 & $\begin{array}{l}\mathrm{N}_{6}-\mathrm{H}_{5}\left(\sigma^{*}\right) \leftarrow \mathrm{O}_{3}(\mathrm{LPs}) \\
\mathrm{N}_{6}-\mathrm{H}_{5}\left(\sigma^{*}\right) \leftarrow \mathrm{C}_{10}-\mathrm{O}_{23}(\pi) \\
\mathrm{C}_{2}-\mathrm{O}_{1}\left(\pi^{*}\right) \leftarrow \mathrm{C}_{11}-\mathrm{O}_{4}(\pi) \\
\mathrm{O}_{1}(\mathrm{LPs}) \rightarrow \mathrm{C}_{7}-\mathrm{H}_{9}\left(\sigma^{*}\right) \\
\mathrm{C}_{5}-\mathrm{N}_{5}(\pi) \rightarrow \mathrm{C}_{10}-\mathrm{O}_{3}\left(\pi^{*}\right) \\
\mathrm{C}_{2}-\mathrm{O}_{1}(\pi) \rightarrow \mathrm{C}_{7}-\mathrm{H}_{9}\left(\sigma^{*}\right) \\
\mathrm{N}_{4}(\mathrm{LP}) \rightarrow \mathrm{C}_{11}-\mathrm{O}_{4}\left(\pi^{*}\right)\end{array}$ & $\begin{array}{l}12.68 \\
7.49 \\
6.65 \\
4.90 \\
4.35 \\
3.72 \\
2.89 \\
\end{array}$ \\
\hline
\end{tabular}




\begin{tabular}{|c|c|c|c|c|c|c|}
\hline $\begin{array}{l}\text { T12 } \\
\text { HB }\end{array}$ & -39.77 & -42.26 & -42.88 & -24.06 & $\begin{array}{l}\mathrm{O}_{1}(\mathrm{LPs}) \rightarrow \mathrm{N}_{7}-\mathrm{H}_{7}\left(\sigma^{*}\right) \\
\mathrm{C}_{5}-\mathrm{H}_{6}\left(\sigma^{*}\right) \leftarrow \mathrm{O}_{3}(\mathrm{LPs})\end{array}$ & $\begin{array}{l}64.89 \\
42.55\end{array}$ \\
\hline
\end{tabular}


Table 3. Binding energies BE and NBO second-order perturbation energy E(2) of cytosine -TMZ dimers

\begin{tabular}{|c|c|c|c|c|c|c|}
\hline Dimer & \multicolumn{4}{|c|}{$\mathrm{BE}(\mathrm{kJ} / \mathrm{mol})$} & \multirow[b]{2}{*}{ TMZ ...cytosine } & \multirow{2}{*}{$\begin{array}{c}\mathrm{NBO} \\
\mathrm{E}(2) \\
(\mathrm{kJ} / \mathrm{mol})\end{array}$} \\
\hline & M06-2X & $\begin{array}{l}\omega \mathrm{B} 97- \\
\mathrm{XD}\end{array}$ & $\begin{array}{l}\text { B3LYP- } \\
\text { D3 }\end{array}$ & MP2 & & \\
\hline $\begin{array}{l}\mathrm{C} 1 \\
\mathrm{P}\end{array}$ & -75.56 & -69.738 & -67.73 & -52.33 & $\begin{array}{l}\mathrm{O}_{2}(\mathrm{LPs}) \rightarrow \mathrm{N}_{9}-\mathrm{H}_{10}\left(\sigma^{*}\right) \\
\mathrm{N}_{3}(\mathrm{LP}) \rightarrow \mathrm{N}_{9}-\mathrm{H}_{10}\left(\sigma^{*}\right) \\
\mathrm{C}_{1}-\mathrm{C}_{4}\left(\pi^{*}\right) \leftarrow \mathrm{N}_{8}(\mathrm{LP}) \\
\mathrm{C}_{2}-\mathrm{O}_{1}\left(\pi^{*}\right) \leftarrow \mathrm{O}_{3}(\mathrm{LPs}) \\
\mathrm{C}_{6}-\mathrm{O}_{2}(\pi) \rightarrow \mathrm{N}_{9}-\mathrm{H}_{10}\left(\sigma^{*}\right)\end{array}$ & $\begin{array}{l}22.22 \\
7.82 \\
5.90 \\
5.82 \\
3.22 \\
\end{array}$ \\
\hline $\begin{array}{l}\mathrm{C} 2 \\
\mathrm{HB}\end{array}$ & -74.06 & -78.671 & -77.84 & -54.64 & $\begin{array}{l}\mathrm{O}_{2}(\mathrm{LPs}) \rightarrow \mathrm{N}_{7}-\mathrm{H}_{7}\left(\sigma^{*}\right) \\
\mathrm{N}_{6}-\mathrm{H}_{4}\left(\sigma^{*}\right) \leftarrow \mathrm{O}_{3}(\mathrm{LPs})\end{array}$ & $\begin{array}{l}124.10 \\
102.84 \\
\end{array}$ \\
\hline $\begin{array}{l}\text { C3 } \\
P\end{array}$ & -72.20 & -65.281 & -64.86 & -50.43 & $\begin{array}{l}\mathrm{O}_{2}(\mathrm{LPs}) \rightarrow \mathrm{N}_{7}-\mathrm{H}_{7}\left(\sigma^{*}\right) \\
\mathrm{N}_{3}(\mathrm{LP}) \rightarrow \mathrm{N}_{7}-\mathrm{H}_{7}\left(\sigma^{*}\right) \\
\mathrm{C}_{1}-\mathrm{C}_{4}\left(\pi^{*}\right) \leftarrow \mathrm{O}_{3}(\mathrm{LPs}) \\
\mathrm{N}_{2}-\mathrm{N}_{3}(\pi) \rightarrow \mathrm{N}_{7}-\mathrm{H}_{7}\left(\sigma^{*}\right) \\
\mathrm{C}_{2}-\mathrm{O}_{1}\left(\pi^{*}\right) \leftarrow \mathrm{O}_{3}(\mathrm{LPs}) \\
\end{array}$ & $\begin{array}{l}14.18 \\
12.80 \\
4.10 \\
3.64 \\
2.55 \\
\end{array}$ \\
\hline $\begin{array}{l}\mathrm{C} 4 \\
\mathrm{~S} 1\end{array}$ & -71.95 & -66.976 & -61.01 & -51.49 & $\begin{array}{l}\mathrm{O}_{2}(\mathrm{LPs}) \rightarrow \mathrm{N}_{9}-\mathrm{H}_{11}\left(\sigma^{*}\right) \\
\mathrm{C}_{6}-\mathrm{O}_{2}(\pi) \rightarrow \mathrm{N}_{9}-\mathrm{H}_{11}\left(\sigma^{*}\right) \\
\mathrm{C}_{3}-\mathrm{H}_{2}\left(\sigma^{*}\right) \leftarrow \mathrm{O}_{3}(\mathrm{LPs}) \\
\mathrm{C}_{3}-\mathrm{H}_{2}\left(\sigma^{*}\right) \leftarrow \mathrm{C}_{9}-\mathrm{O}_{3}(\pi) \\
\mathrm{C}_{1}-\mathrm{C}_{4}(\pi) \rightarrow \mathrm{N}_{8}-\mathrm{C}_{10}\left(\pi^{*}\right) \\
\mathrm{C}_{1}-\mathrm{C}_{4}(\pi) \rightarrow \mathrm{C}_{7}-\mathrm{C}_{8}\left(\pi^{*}\right) \\
\mathrm{C}_{1}-\mathrm{C}_{4}\left(\pi^{*}\right) \leftarrow \mathrm{N}_{8}-\mathrm{C}_{10}(\pi)\end{array}$ & $\begin{array}{l}26.23 \\
11.84 \\
6.07 \\
3.81 \\
3.47 \\
2.80 \\
2.64 \\
\end{array}$ \\
\hline $\begin{array}{l}\mathrm{C} 5 \\
\mathrm{~S} 2\end{array}$ & -70.29 & -60.606 & -55.19 & -46.22 & $\begin{array}{l}\mathrm{C}_{1}-\mathrm{N}_{4}(\pi) \rightarrow \mathrm{C}_{9}-\mathrm{O}_{3}\left(\pi^{*}\right) \\
\mathrm{C}_{6}-\mathrm{O}_{2}(\pi) \rightarrow \mathrm{C}_{7}-\mathrm{C}_{8}\left(\pi^{*}\right) \\
\mathrm{C}_{6}-\mathrm{O}_{2}\left(\pi^{*}\right) \leftarrow \mathrm{C}_{7}-\mathrm{C}_{8}(\pi) \\
\mathrm{C}_{2}-\mathrm{O}_{1}\left(\pi^{*}\right) \leftarrow \mathrm{C}_{9}-\mathrm{O}_{3}(\pi) \\
\mathrm{C}_{1}-\mathrm{N}_{4}\left(\pi^{*}\right) \leftarrow \mathrm{N}_{7}(\mathrm{LP}) \\
\mathrm{C}_{1}-\mathrm{N}_{4}\left(\pi^{*}\right) \leftarrow \mathrm{C}_{9}-\mathrm{O}_{3}(\pi)\end{array}$ & $\begin{array}{l}3.10 \\
2.97 \\
2.55 \\
2.55 \\
2.18 \\
2.13 \\
\end{array}$ \\
\hline $\begin{array}{l}\mathrm{C} 6 \\
\mathrm{HB}\end{array}$ & -69.06 & -73.232 & -72.63 & -49.03 & $\begin{array}{l}\mathrm{O}_{2}(\mathrm{LPs}) \rightarrow \mathrm{N}_{9}-\mathrm{H}_{10}\left(\sigma^{*}\right) \\
\mathrm{N}_{6}-\mathrm{H}_{4}\left(\sigma^{*}\right) \leftarrow \mathrm{N}_{8}(\mathrm{LP})\end{array}$ & $\begin{array}{l}92.47 \\
80.00\end{array}$ \\
\hline $\begin{array}{l}\text { C7 } \\
\text { S2 }\end{array}$ & -64.73 & -57.121 & -51.03 & -40.56 & $\begin{array}{l}\mathrm{C}_{2}-\mathrm{O}_{1}\left(\pi^{*}\right) \leftarrow \mathrm{N}_{8}-\mathrm{C}_{10}(\pi) \\
\mathrm{C}_{2}-\mathrm{O}_{1}\left(\pi^{*}\right) \leftarrow \mathrm{N}_{8}(\mathrm{LP}) \\
\mathrm{N}_{2}-\mathrm{N}_{3}\left(\pi^{*}\right) \leftarrow \mathrm{C}_{9}-\mathrm{O}_{3}(\pi) \\
\mathrm{C}_{5}-\mathrm{N}_{5}\left(\sigma^{*}\right) \leftarrow \mathrm{N}_{9}(\mathrm{LP}) \\
\mathrm{N}_{2}-\mathrm{N}_{3}\left(\pi^{*}\right) \leftarrow \mathrm{N}_{7}(\mathrm{LP})\end{array}$ & $\begin{array}{l}6.02 \\
3.60 \\
2.92 \\
2.34 \\
2.30 \\
\end{array}$ \\
\hline $\begin{array}{l}\mathrm{C} 8 \\
\mathrm{~S} 2\end{array}$ & -63.59 & -55.264 & -49.13 & -38.41 & $\begin{array}{l}\mathrm{C}_{1}-\mathrm{C}_{4}(\pi) \rightarrow \mathrm{N}_{8}-\mathrm{C}_{10}\left(\pi^{*}\right) \\
\mathrm{N}_{2}-\mathrm{N}_{3}(\pi) \rightarrow \mathrm{C}_{9}-\mathrm{O}_{3}\left(\pi^{*}\right) \\
\mathrm{C}_{3}-\mathrm{H}_{3}\left(\pi^{*}\right) \leftarrow \mathrm{O}_{3}(\mathrm{LPs}) \\
\mathrm{C}_{1}-\mathrm{C}_{4}\left(\pi^{*}\right) \leftarrow \mathrm{N}_{8}-\mathrm{C}_{10}(\pi) \\
\mathrm{N}_{2}-\mathrm{N}_{3}\left(\pi^{*}\right) \leftarrow \mathrm{C}_{9}-\mathrm{O}_{3}(\pi) \\
\mathrm{C}_{2}-\mathrm{O}_{1}\left(\pi^{*}\right) \leftarrow \mathrm{N}_{8}(\mathrm{LP})\end{array}$ & $\begin{array}{l}4.56 \\
4.18 \\
3.26 \\
3.14 \\
2.47 \\
2.18 \\
\end{array}$ \\
\hline $\begin{array}{l}\text { C9 } \\
\text { S1 }\end{array}$ & -62.39 & -57.466 & -54.69 & -42.55 & $\begin{array}{l}\mathrm{O}_{2}(\mathrm{LPs}) \rightarrow \mathrm{N}_{9}-\mathrm{H}_{11}\left(\sigma^{*}\right) \\
\mathrm{C}_{3}-\mathrm{H}_{2}\left(\pi^{*}\right) \leftarrow \mathrm{O}_{3}(\mathrm{LPs}) \\
\mathrm{C}_{6}-\mathrm{O}_{2}(\pi) \rightarrow \mathrm{N}_{9}-\mathrm{H}_{11}\left(\sigma^{*}\right) \\
\mathrm{C}_{3}-\mathrm{H}_{2}\left(\sigma^{*}\right) \leftarrow \mathrm{C}_{9}-\mathrm{O}_{3}(\pi) \\
\mathrm{N}_{3}(\mathrm{LP}) \rightarrow \mathrm{C}_{9}-\mathrm{O}_{3}\left(\pi^{*}\right)\end{array}$ & $\begin{array}{l}10.38 \\
6.28 \\
5.44 \\
3.68 \\
2.51 \\
\end{array}$ \\
\hline
\end{tabular}




\begin{tabular}{|c|c|c|c|c|c|c|}
\hline & & & & & $\begin{array}{l}\mathrm{C}_{1}-\mathrm{C}_{4}\left(\pi^{*}\right) \leftarrow \mathrm{N}_{8}-\mathrm{C}_{10}(\pi) \\
\mathrm{N}_{4}(\mathrm{LP}) \rightarrow \mathrm{N}_{8}-\mathrm{C}_{10}\left(\pi^{*}\right)\end{array}$ & $\begin{array}{l}2.30 \\
2.13\end{array}$ \\
\hline $\begin{array}{l}\text { C10 } \\
\text { P }\end{array}$ & -51.48 & -48.180 & -45.86 & -31.43 & $\begin{array}{l}\mathrm{O}_{1}(\mathrm{LPs}) \rightarrow \mathrm{N}_{9}-\mathrm{H}_{10}\left(\sigma^{*}\right) \\
\mathrm{C}_{2}-\mathrm{O}_{1}\left(\pi^{*}\right) \leftarrow \mathrm{N}_{8}(\mathrm{LP}) \\
\mathrm{C}_{2}-\mathrm{O}_{1}(\pi) \rightarrow \mathrm{N}_{9}-\mathrm{H}_{10}\left(\sigma^{*}\right)\end{array}$ & $\begin{array}{l}19.29 \\
16.61 \\
10.08 \\
\end{array}$ \\
\hline $\begin{array}{l}\text { C11 } \\
\text { HB }\end{array}$ & -46.56 & -49.990 & -49.29 & -28.25 & $\begin{array}{l}\mathrm{N}_{6}-\mathrm{H}_{5}\left(\sigma^{*}\right) \leftarrow \mathrm{N}_{8}(\mathrm{LP}) \\
\mathrm{N}_{5}(\mathrm{LP}) \rightarrow \mathrm{N}_{9}-\mathrm{H}_{10}\left(\sigma^{*}\right)\end{array}$ & $\begin{array}{l}66.65 \\
43.14 \\
\end{array}$ \\
\hline $\begin{array}{l}\mathrm{C} 12 \\
\mathrm{HB}\end{array}$ & -43.10 & -46.092 & -46.00 & -26.23 & $\begin{array}{l}\mathrm{O}_{1}(\mathrm{LPs}) \rightarrow \mathrm{N}_{7}-\mathrm{H}_{7}\left(\sigma^{*}\right) \\
\mathrm{C}_{5}-\mathrm{H}_{6}\left(\pi^{*}\right) \leftarrow \mathrm{O}_{3}(\mathrm{LPs})\end{array}$ & $\begin{array}{l}59.66 \\
53.72\end{array}$ \\
\hline
\end{tabular}


Table 4. Binding energies BE and NBO second-order perturbation energy E(2) of adenine -TMZ dimers

\begin{tabular}{|c|c|c|c|c|c|c|}
\hline Dimer & \multicolumn{4}{|c|}{$\mathrm{BE}(\mathrm{kJ} / \mathrm{mol})$} & \multirow[b]{2}{*}{ TMZ...adenine } & \multirow{2}{*}{$\begin{array}{l}\mathrm{NBO} \mathrm{E}(2) \\
(\mathrm{kJ} / \mathrm{mol})\end{array}$} \\
\hline & M06-2X & $\begin{array}{l}\omega \mathrm{B} 97- \\
\text { XD }\end{array}$ & $\begin{array}{l}\text { B3LYP- } \\
\text { D3 }\end{array}$ & MP2 & & \\
\hline $\begin{array}{l}\text { A1 } \\
P\end{array}$ & -68.73 & -68.64 & -65.06 & -54.79 & $\begin{array}{l}\mathrm{O}_{2}(\mathrm{LPs}) \rightarrow \mathrm{N}_{9}-\mathrm{H}_{11}\left(\sigma^{*}\right) \\
\mathrm{C}_{6}-\mathrm{O}_{2}(\pi) \rightarrow \mathrm{N}_{9}-\mathrm{H}_{11}\left(\sigma^{*}\right) \\
\mathrm{C}_{1}-\mathrm{C}_{4}\left(\pi^{*}\right) \leftarrow \mathrm{N}_{8}(\mathrm{LP}) \\
\mathrm{N}_{3}(\mathrm{LP}) \rightarrow \mathrm{N}_{9}-\mathrm{H}_{11}\left(\sigma^{*}\right) \\
\mathrm{C}_{2}-\mathrm{O}_{1}\left(\pi^{*}\right) \leftarrow \mathrm{N}_{8}(\mathrm{LP})\end{array}$ & $\begin{array}{l}56.82 \\
7.07 \\
5.40 \\
4.31 \\
3.60 \\
\end{array}$ \\
\hline $\begin{array}{l}\mathrm{A} 2 \\
\mathrm{HB}\end{array}$ & -67.03 & -72.22 & -71.15 & -50.00 & $\begin{array}{l}\mathrm{O}_{2}(\mathrm{LPs}) \rightarrow \mathrm{N}_{9}-\mathrm{H}_{11}\left(\sigma^{*}\right) \\
\mathrm{N}_{6}-\mathrm{H}_{4}\left(\sigma^{*}\right) \leftarrow \mathrm{N}_{8}(\mathrm{LP})\end{array}$ & $\begin{array}{l}113.39 \\
75.69\end{array}$ \\
\hline $\begin{array}{l}\text { A3 } \\
\text { S1 }\end{array}$ & -64.27 & -58.85 & -51.16 & -49.89 & $\begin{array}{l}\mathrm{O}_{2}(\mathrm{LPs}) \rightarrow \mathrm{N}_{9}-\mathrm{H}_{11}\left(\sigma^{*}\right) \\
\mathrm{C}_{6}-\mathrm{O}_{2}(\pi) \rightarrow \mathrm{N}_{9}-\mathrm{H}_{11}\left(\sigma^{*}\right) \\
\mathrm{C}_{2}-\mathrm{O}_{1}(\pi) \rightarrow \mathrm{N}_{11}-\mathrm{H}_{10}\left(\sigma^{*}\right) \\
\mathrm{N}_{2}-\mathrm{N}_{3}(\pi) \rightarrow \mathrm{C}_{11}-\mathrm{N}_{10}\left(\pi^{*}\right) \\
\mathrm{C}_{1}-\mathrm{N}_{4}\left(\pi^{*}\right) \leftarrow \mathrm{C}_{11}-\mathrm{N}_{10}(\pi) \\
\mathrm{C}_{2}-\mathrm{O}_{1}\left(\pi^{*}\right) \leftarrow \mathrm{C}_{11}-\mathrm{N}_{10}(\pi) \\
\mathrm{C}_{2}-\mathrm{O}_{1}\left(\pi^{*}\right) \leftarrow \mathrm{N}_{10}(\mathrm{LP})\end{array}$ & $\begin{array}{l}6.61 \\
5.56 \\
3.60 \\
3.56 \\
3.43 \\
2.18 \\
2.09 \\
\end{array}$ \\
\hline $\begin{array}{l}\text { A4 } \\
\text { S1 }\end{array}$ & -61.86 & -60.67 & -53.47 & -51.45 & $\begin{array}{l}\mathrm{O}_{2}(\mathrm{LPs}) \rightarrow \mathrm{N}_{9}-\mathrm{H}_{11}\left(\sigma^{*}\right) \\
\mathrm{C}_{3}-\mathrm{H}_{2}\left(\sigma^{*}\right) \leftarrow \mathrm{N}_{11}(\mathrm{LP}) \\
\mathrm{C}_{6}-\mathrm{O}_{2}(\pi) \rightarrow \mathrm{N}_{9}-\mathrm{H}_{11}\left(\sigma^{*}\right) \\
\mathrm{C}_{1}-\mathrm{C}_{4}(\pi) \rightarrow \mathrm{C}_{9}-\mathrm{N}_{9}\left(\pi^{*}\right) \\
\mathrm{N}_{2}-\mathrm{N}_{3}\left(\pi^{*}\right) \leftarrow \mathrm{C}_{9}-\mathrm{N}_{9}(\pi) \\
\mathrm{C}_{1}-\mathrm{C}_{4}(\pi) \rightarrow \mathrm{N}_{8}-\mathrm{C}_{10}\left(\pi^{*}\right)\end{array}$ & $\begin{array}{l}29.08 \\
8.03 \\
7.57 \\
3.85 \\
3.14 \\
2.26 \\
\end{array}$ \\
\hline $\begin{array}{l}\text { A5 } \\
\text { S2 }\end{array}$ & -59.43 & -54.73 & -45.20 & -40.66 & $\begin{array}{l}\mathrm{C}_{2}-\mathrm{O}_{1}\left(\pi^{*}\right) \leftarrow \mathrm{N}_{8}-\mathrm{C}_{10}(\pi) \\
\mathrm{C}_{6}-\mathrm{O}_{2}(\pi) \rightarrow \mathrm{C}_{11}-\mathrm{N}_{10}\left(\pi^{*}\right) \\
\mathrm{C}_{6}-\mathrm{O}_{2}\left(\pi^{*}\right) \leftarrow \mathrm{C}_{11}-\mathrm{N}_{10}(\pi) \\
\mathrm{C}_{2}-\mathrm{O}_{1}(\pi) \rightarrow \mathrm{N}_{8}-\mathrm{C}_{10}\left(\pi^{*}\right)\end{array}$ & $\begin{array}{l}5.69 \\
4.14 \\
2.38 \\
2.01 \\
\end{array}$ \\
\hline $\begin{array}{l}\text { A6 } \\
\text { S1 }\end{array}$ & -59.13 & -54.12 & -45.70 & -39.31 & $\begin{array}{l}\mathrm{O}_{2}(\mathrm{LPs}) \rightarrow \mathrm{N}_{11}-\mathrm{H}_{9}\left(\sigma^{*}\right) \\
\mathrm{C}_{6}-\mathrm{O}_{2}(\pi) \rightarrow \mathrm{N}_{11}-\mathrm{H}_{9}\left(\sigma^{*}\right) \\
\mathrm{C}_{2}-\mathrm{O}_{1}\left(\pi^{*}\right) \leftarrow \mathrm{C}_{11}-\mathrm{N}_{10}(\pi) \\
\mathrm{C}_{1}-\mathrm{C}_{4}(\pi) \rightarrow \mathrm{N}_{7}-\mathrm{C}_{7}\left(\pi^{*}\right) \\
\mathrm{C}_{6}-\mathrm{O}_{2}\left(\pi^{*}\right) \leftarrow \mathrm{N}_{7}-\mathrm{C}_{7}(\pi) \\
\mathrm{C}_{2}-\mathrm{O}_{1}(\pi) \rightarrow \mathrm{C}_{11}-\mathrm{N}_{10}\left(\pi^{*}\right) \\
\mathrm{C}_{5}-\mathrm{N}_{5}(\pi) \rightarrow \mathrm{C}_{9}-\mathrm{N}_{9}\left(\pi^{*}\right) \\
\mathrm{C}_{1}-\mathrm{C}_{4}\left(\pi^{*}\right) \leftarrow \mathrm{N}_{7}-\mathrm{C}_{7}(\pi)\end{array}$ & $\begin{array}{l}6.82 \\
5.86 \\
5.56 \\
5.48 \\
3.10 \\
2.64 \\
2.22 \\
2.09 \\
\end{array}$ \\
\hline $\begin{array}{l}\text { A7 } \\
\text { S1 }\end{array}$ & -56.61 & -54.54 & -47.86 & -41.83 & $\begin{array}{l}\mathrm{O}_{2}(\mathrm{LPs}) \rightarrow \mathrm{N}_{11}-\mathrm{H}_{10}\left(\sigma^{*}\right) \\
\mathrm{C}_{6}-\mathrm{O}_{2}(\pi) \rightarrow \mathrm{N}_{11}-\mathrm{H}_{10}\left(\sigma^{*}\right) \\
\mathrm{C}_{3}-\mathrm{H}_{1}\left(\sigma^{*}\right) \leftarrow \mathrm{N}_{8}(L P) \\
\mathrm{N}_{1}(\mathrm{LP}) \rightarrow \mathrm{C}_{9}-\mathrm{N}_{9}\left(\pi^{*}\right) \\
\mathrm{C}_{2}-\mathrm{O}_{1}\left(\pi^{*}\right) \leftarrow \mathrm{C}_{9}-\mathrm{N}_{9}(\pi)\end{array}$ & $\begin{array}{l}25.82 \\
7.53 \\
4.52 \\
3.64 \\
2.97\end{array}$ \\
\hline A8 S2 & -52.21 & -48.71 & -41.48 & -35.27 & $\mathrm{~N}_{2}-\mathrm{N}_{3}(\pi) \rightarrow \mathrm{C}_{9}-\mathrm{N}_{9}\left(\pi^{*}\right)$ & 2.89 \\
\hline $\begin{array}{l}\text { A9 } \\
P\end{array}$ & -52.10 & -51.03 & -47.59 & -37.52 & $\begin{array}{l}\left.\mathrm{C}_{2}-\mathrm{O}_{1}(\pi)\right) \rightarrow \mathrm{N}_{11}-\mathrm{H}_{10}\left(\sigma^{*}\right) \\
\mathrm{O}_{1}(\mathrm{LPs}) \rightarrow \mathrm{N}_{11}-\mathrm{H}_{10}\left(\sigma^{*}\right) \\
\mathrm{C}_{2}-\mathrm{O}_{1}\left(\pi^{*}\right) \leftarrow \mathrm{N}_{10}(L P) \\
\mathrm{O}_{2}(\mathrm{LPs}) \rightarrow \mathrm{C}_{11}-\mathrm{H}_{8}\left(\sigma^{*}\right) \\
\mathrm{C}_{3}-\mathrm{H}_{3}\left(\sigma^{*}\right) \leftarrow \mathrm{N}_{11}(\mathrm{LP})\end{array}$ & $\begin{array}{l}12.97 \\
9.79 \\
7.70 \\
6.90 \\
4.35 \\
\end{array}$ \\
\hline
\end{tabular}




\begin{tabular}{|l|l|l|l|l|l|l|}
\hline & & & & & $\mathrm{C}_{1}-\mathrm{C}_{4}\left(\pi^{*}\right) \leftarrow \mathrm{N}_{10}(\mathrm{LP})$ & 3.30 \\
& & & & & $\mathrm{C}_{6}-\mathrm{O}_{2}(\pi) \rightarrow \mathrm{C}_{11}-\mathrm{H}_{8}\left(\sigma^{*}\right)$ & 2.64 \\
\hline S10 & -51.10 & -49.77 & -45.49 & -35.11 & $\mathrm{O}_{2}(\mathrm{LPs}) \rightarrow \mathrm{N}_{11}-\mathrm{H}_{9}\left(\sigma^{*}\right)$ & 30.50 \\
& & & & & $\mathrm{C}_{6}-\mathrm{O}_{2}(\pi) \rightarrow \mathrm{N}_{11}-\mathrm{H}_{9}\left(\sigma^{*}\right)$ & 7.11 \\
& & & & $\mathrm{C}_{1}-\mathrm{C}_{4}\left(\pi^{*}\right) \leftarrow \mathrm{N}_{7}-\mathrm{C}_{7}(\pi)$ & 2.97 \\
& & & & $\mathrm{~N}_{2}-\mathrm{N}_{3}(\pi) \rightarrow \mathrm{N}_{7}-\mathrm{C}_{7}\left(\pi^{*}\right)$ & 2.85 \\
& & & & $\mathrm{~N}_{2}-\mathrm{N}_{3}\left(\pi^{*}\right) \leftarrow \mathrm{N}_{11}(\mathrm{LP})$ & 2.55 \\
& & & & $\mathrm{C}_{3}-\mathrm{H}_{2}\left(\sigma^{*}\right) \leftarrow \mathrm{N}_{8}(\mathrm{LP})$ & 2.38 \\
& & & & $\mathrm{C}_{3}-\mathrm{H}_{2}\left(\sigma^{*}\right) \leftarrow \mathrm{N}_{8}-\mathrm{C}_{10}(\pi)$ & 2.22 \\
A11 & -50.54 & -55.13 & -55.21 & -32.66 & $\mathrm{C}_{1}-\mathrm{C}_{4}\left(\pi^{*}\right) \leftarrow \mathrm{N}_{7}(\mathrm{LP})$ & 2.13 \\
\hline HB & & & & & $\mathrm{O}_{2}(\mathrm{LPs}) \rightarrow \mathrm{N}_{11}-\mathrm{H}_{10}\left(\sigma^{*}\right)$ & 75.81 \\
& & & & & \\
\end{tabular}


Table 5. Binding energies BE and NBO second-order perturbation energy E(2) of guanine -TMZ dimers

\begin{tabular}{|c|c|c|c|c|c|c|}
\hline Dimer & \multicolumn{4}{|c|}{$\mathrm{BE}(\mathrm{kJ} / \mathrm{mol})$} & \multirow[b]{2}{*}{ TMZ...guanine } & \multirow{2}{*}{$\begin{array}{l}\mathrm{NBO} \mathrm{E}(2) \\
(\mathrm{kJ} / \mathrm{mol})\end{array}$} \\
\hline & M062X & $\begin{array}{l}\omega B 97 X \\
D\end{array}$ & $\begin{array}{l}\text { B3LYP- } \\
\text { D3 }\end{array}$ & MP2 & & \\
\hline $\begin{array}{l}\text { G1 } \\
P\end{array}$ & -81.56 & -77.04 & -76.65 & -56.94 & $\begin{array}{l}\mathrm{O}_{2}(\mathrm{LPs}) \rightarrow \mathrm{N}_{11}-\mathrm{H}_{10}\left(\sigma^{*}\right) \\
\mathrm{N}_{3}(\mathrm{LP}) \rightarrow \mathrm{N}_{9}-\mathrm{H}_{8}\left(\sigma^{*}\right) \\
\mathrm{O}_{2}(\mathrm{LPS}) \rightarrow \mathrm{N}_{9}-\mathrm{H}_{8}\left(\sigma^{*}\right) \\
\mathrm{C}_{6}-\mathrm{O}_{2}(\pi) \rightarrow \mathrm{N}_{11}-\mathrm{H}_{10}\left(\sigma^{*}\right) \\
\mathrm{C}_{1}-\mathrm{C}_{4}\left(\pi^{*}\right) \leftarrow \mathrm{O}_{3}(\mathrm{LPs} \\
\mathrm{N}_{2}-\mathrm{N}_{3}(\pi) \rightarrow \mathrm{N}_{9}-\mathrm{H}_{8}\left(\sigma^{*}\right) \\
\mathrm{C}_{2}-\mathrm{O}_{1}\left(\pi^{*}\right) \leftarrow \mathrm{O}_{3}(\mathrm{LPs})\end{array}$ & $\begin{array}{l}28.95 \\
14.35 \\
9.25 \\
6.65 \\
4.03 \\
3.68 \\
2.51 \\
\end{array}$ \\
\hline $\begin{array}{l}\text { G2 } \\
\text { HB }\end{array}$ & -77.50 & -81.92 & -81.58 & -54.53 & $\begin{array}{l}\mathrm{O}_{2}(\mathrm{LPS}) \rightarrow \mathrm{N}_{9}-\mathrm{H}_{8}\left(\sigma^{*}\right) \\
\mathrm{N}_{6}-\mathrm{H}_{4}\left(\sigma^{*}\right) \leftarrow \mathrm{O}_{3}(\mathrm{LPs}) \\
\mathrm{O}_{2}(\mathrm{LPs}) \rightarrow \mathrm{N}_{11}-\mathrm{H}_{10}\left(\sigma^{*}\right)\end{array}$ & $\begin{array}{l}136.86 \\
122.50 \\
3.77 \\
\end{array}$ \\
\hline $\begin{array}{l}\text { G3 } \\
\text { S2 }\end{array}$ & -71.58 & -61.24 & -54.77 & -46.96 & $\begin{array}{l}\mathrm{C}_{2}-\mathrm{O}_{1}(\pi) \leftarrow \mathrm{C}_{10}-\mathrm{O}_{3}(\pi) \\
\mathrm{C}_{1}-\mathrm{C}_{4}(\pi) \rightarrow \mathrm{C}_{10}-\mathrm{O}_{3}\left(\pi^{*}\right) \\
\mathrm{C}_{6}-\mathrm{O}_{2}(\pi) \leftarrow \mathrm{C}_{11}-\mathrm{N}_{10}(\pi) \\
\mathrm{C}_{5}-\mathrm{N}_{5}\left(\pi^{*}\right) \leftarrow \mathrm{N}_{8}(\mathrm{LP}) \\
\mathrm{N}_{2}-\mathrm{N}_{3}\left(\pi^{*}\right) \leftarrow \mathrm{N}_{9}(\mathrm{LP}) \\
\mathrm{C}_{2}-\mathrm{O}_{1}\left(\pi^{*}\right) \leftarrow \mathrm{O}_{3}(\mathrm{LPs})\end{array}$ & $\begin{array}{l}4.56 \\
4.31 \\
4.02 \\
3.22 \\
2.55 \\
2.18 \\
\end{array}$ \\
\hline $\begin{array}{l}\text { G4 } \\
\text { S1 }\end{array}$ & -70.93 & -64.12 & -58.63 & -52.14 & $\begin{array}{l}\mathrm{O}_{2}(\mathrm{LPs}) \rightarrow \mathrm{N}_{8}-\mathrm{H}_{7}\left(\sigma^{*}\right) \mathrm{C}_{6^{-}} \\
\left.\mathrm{O}_{2}(\pi) \rightarrow \mathrm{N}_{8}-\mathrm{H}_{7} \sigma^{*}\right) \\
\mathrm{N}_{2}-\mathrm{N}_{3}\left(\pi^{*}\right) \leftarrow \mathrm{N}_{8}(\mathrm{LP}) \\
\mathrm{C}_{2}-\mathrm{O}_{1}(\pi) \rightarrow \mathrm{C}_{11}-\mathrm{N}_{10}\left(\pi^{*}\right) \\
\mathrm{C}_{2}-\mathrm{O}_{1}(\pi) \rightarrow \mathrm{C}_{11}-\mathrm{N}_{10}\left(\pi^{*}\right)\end{array}$ & $\begin{array}{l}34.18 \\
8.41 \\
3.89 \\
2.76 \\
2.76 \\
\end{array}$ \\
\hline $\begin{array}{l}\text { G5 } \\
P\end{array}$ & -70.66 & -65.39 & -64.67 & -50.30 & $\begin{array}{l}\mathrm{N}_{3}(\mathrm{LP}) \rightarrow \mathrm{N}_{8}-\mathrm{H}_{7}\left(\sigma^{*}\right) \\
\mathrm{O}_{2}(\mathrm{LPs}) \rightarrow \mathrm{N}_{8}-\mathrm{H}_{7}\left(\sigma^{*}\right) \\
\mathrm{C}_{2}-\mathrm{O}_{1}\left(\pi^{*}\right) \leftarrow \mathrm{O}_{3}(\mathrm{LPs}) \\
\mathrm{N}_{2}-\mathrm{N}_{3}(\pi) \rightarrow \mathrm{N}_{8}-\mathrm{H}_{7}\left(\sigma^{*}\right) \\
\mathrm{C}_{1}-\mathrm{C}_{4}\left(\pi^{*}\right) \leftarrow \mathrm{O}_{3}(\mathrm{LPs})\end{array}$ & $\begin{array}{l}21.88 \\
16.69 \\
4.77 \\
2.64 \\
2.51 \\
\end{array}$ \\
\hline $\begin{array}{l}\text { G6 } \\
\text { HB }\end{array}$ & -70.40 & -75.09 & -75.07 & -53.46 & $\begin{array}{l}\mathrm{O}_{2}(\mathrm{LPs}) \rightarrow \mathrm{N}_{8}-\mathrm{H}_{7}\left(\sigma^{*}\right) \\
\mathrm{N}_{6}-\mathrm{H}_{4}\left(\sigma^{*}\right) \leftarrow \mathrm{O}_{3}(\mathrm{LPs})\end{array}$ & $\begin{array}{l}128.32 \\
82.34\end{array}$ \\
\hline $\begin{array}{l}\text { G7 } \\
\text { S1 }\end{array}$ & -67.36 & -57.49 & -49.38 & -46.74 & $\begin{array}{l}\mathrm{O}_{2}(\mathrm{LPs}) \rightarrow \mathrm{N}_{8}-\mathrm{H}_{7}\left(\sigma^{*}\right) \\
\mathrm{C}_{2}-\mathrm{O}_{1}\left(\pi^{*}\right) \leftarrow \mathrm{C}_{11}-\mathrm{N}_{10}(\pi) \\
\mathrm{C}_{1}-\mathrm{C}_{4}\left(\pi^{*}\right) \leftarrow \mathrm{C}_{8}-\mathrm{C}_{9}(\pi) \\
\mathrm{C}_{1}-\mathrm{C}_{4}(\pi) \rightarrow \mathrm{C}_{10}-\mathrm{O}_{3}\left(\pi^{*}\right) \\
\mathrm{C}_{6}-\mathrm{O}_{2}(\pi) \rightarrow \mathrm{N}_{8}-\mathrm{H}_{7}\left(\sigma^{*}\right) \\
\mathrm{C}_{3}-\mathrm{H}_{2}\left(\sigma^{*}\right) \leftarrow \mathrm{N}_{10}(\mathrm{LP})\end{array}$ & $\begin{array}{l}73.51 \\
4.90 \\
4.69 \\
4.44 \\
3.35 \\
2.18\end{array}$ \\
\hline $\begin{array}{l}\text { G8 } \\
\text { HB }\end{array}$ & -62.99 & -68.61 & -67.02 & -38.90 & $\begin{array}{l}\mathrm{O}_{2}(\mathrm{LPs}) \rightarrow \mathrm{N}_{11}-\mathrm{H}_{11}\left(\sigma^{*}\right) \\
\mathrm{N}_{6}-\mathrm{H}_{4}\left(\sigma^{*}\right) \leftarrow \mathrm{N}_{10}(\mathrm{LP})\end{array}$ & $\begin{array}{l}97.32 \\
76.73 \\
\end{array}$ \\
\hline $\begin{array}{l}\text { G9 } \\
\text { S1 }\end{array}$ & -61.43 & -58.48 & -53.22 & -43.00 & $\begin{array}{l}\mathrm{O}_{2}(\mathrm{LPs}) \rightarrow \mathrm{N}_{9}-\mathrm{H}_{8}\left(\sigma^{*}\right) \\
\mathrm{C}_{6}-\mathrm{O}_{2}(\pi) \rightarrow \mathrm{N}_{11}-\mathrm{H}_{10}\left(\sigma^{*}\right) \\
\mathrm{O}_{2}(\mathrm{LPs}) \rightarrow \mathrm{N}_{11}-\mathrm{H}_{10}\left(\sigma^{*}\right) \\
\mathrm{N}_{2}-\mathrm{N}_{3}\left(\pi^{*}\right) \leftarrow \mathrm{C}_{8}-\mathrm{C}_{9}(\pi) \\
\mathrm{C}_{1}-\mathrm{C}_{4}\left(\pi^{*}\right) \leftarrow \mathrm{C}_{11}-\mathrm{N}_{10}(\pi) \\
\mathrm{C}_{3}-\mathrm{H}_{3}\left(\sigma^{*}\right) \leftarrow \mathrm{N}_{10}(\mathrm{LP})\end{array}$ & $\begin{array}{l}11.97 \\
9.50 \\
4.31 \\
3.43 \\
3.01 \\
2.93\end{array}$ \\
\hline
\end{tabular}




\begin{tabular}{|l|l|l|l|l|l|l|}
\hline G10 & -61.24 & -55.43 & -46.06 & -40.33 & $\mathrm{C}_{11}-\mathrm{O}_{14}\left(\pi^{*}\right) \leftarrow \mathrm{N}_{8}(\mathrm{LP})$ & 4.14 \\
S1 & & & & & $\mathrm{N}_{1}(\mathrm{LP}) \rightarrow \mathrm{N}_{8}-\mathrm{H}_{7}\left(\sigma^{*}\right)$ & 3.60 \\
& & & & & $\mathrm{C}_{5}-\mathrm{N}_{5}(\pi) \rightarrow \mathrm{C}_{10}-\mathrm{O}_{3}\left(\pi^{*}\right)$ & 3.10 \\
& & & & & $\mathrm{~N}_{6}-\mathrm{H}_{5}\left(\sigma^{*}\right) \leftarrow \mathrm{C}_{10}-\mathrm{O}_{3}(\pi)$ & 2.76 \\
& & & & & $\mathrm{C}_{2}-\mathrm{O}_{1}\left(\pi^{*}\right) \leftarrow \mathrm{C}_{11}-\mathrm{N}_{10}(\pi)$ & 2.55 \\
\hline G11 & -60.77 & -61.88 & -60.67 & -40.23 & $\mathrm{C}_{2}-\mathrm{O}_{1}\left(\sigma^{*}\right) \leftarrow \mathrm{N}_{32}(\mathrm{LP})$ & 2.05 \\
\hline HB & & & & & $\mathrm{O}_{2}(\mathrm{LPs}) \rightarrow \mathrm{N}_{9}-\mathrm{H}_{8}\left(\sigma^{*}\right)$ & 52.05 \\
& & & & & $\mathrm{O}_{2}(\mathrm{LPs}) \rightarrow \mathrm{N}_{11}-\mathrm{H}_{10}\left(\sigma^{*}\right)$ & 28.53 \\
\hline
\end{tabular}


Table 6. Comparison between B3LYP and B3LYP-D3 binding energies $(\mathrm{kJ} / \mathrm{mol})$ of uracil-TMZ dimers.

\begin{tabular}{|l|l|l|c|}
\hline Dimer & $\begin{array}{l}\text { B3LYP- } \\
\text { D3 }\end{array}$ & B3LYP & $\Delta$ BE \\
\hline U1 HB & -74.50 & -61.53 & -12.97 \\
\hline U2 P & -62.67 & -29.58 & -33.08 \\
\hline U3 S1 & -55.12 & -3.27 & -51.85 \\
\hline U4 S2 & -47.95 & 4.81 & -52.76 \\
\hline U5 HB & -55.91 & -43.18 & -12.73 \\
\hline U6 HB & -52.23 & -39.64 & -12.59 \\
\hline U7 S1 & -39.10 & 18.20 & -57.20 \\
\hline U8 HB & -54.08 & -34.50 & -19.58 \\
\hline U9 HB & -53.19 & -33.64 & -19.55 \\
\hline U10 HB & -43.12 & -31.29 & -11.83 \\
\hline U11 HB & -36.31 & -24.99 & -11.70 \\
\hline U12 HB & -34.63 & -22.96 & -11.67 \\
\hline
\end{tabular}

Table 7. Comparison between B3LYP and B3LYP-D3 binding energies $(\mathrm{kJ} / \mathrm{mol})$ of thymineTMZ dimers.

\begin{tabular}{|l|l|l|c|}
\hline Dimer & $\begin{array}{l}\text { B3LYP- } \\
\text { D3 }\end{array}$ & B3LYP & $\Delta$ BE \\
\hline T1 HB & -73.78 & -60.72 & -13.06 \\
\hline T2 P & -62.02 & -28.82 & -33.20 \\
\hline T3 S1 & -55.44 & -1.33 & -54.11 \\
\hline T4 S2 & -44.91 & 18.55 & -63.46 \\
\hline T5 S1 & -49.74 & 7.22 & -56.96 \\
\hline T6 S1 & -46.56 & 17.17 & -63.73 \\
\hline T7 HB & -54.87 & -41.81 & -13.06 \\
\hline T8 HB & -52.82 & -40.08 & -12.74 \\
\hline T9 HB & -54.45 & -34.51 & -19.94 \\
\hline T10 HB & -53.73 & -33.86 & -19.87 \\
\hline T11 S1 & -37.39 & 18.21 & -55.60 \\
\hline T12 HB & -42.88 & -30.90 & -11.98 \\
\hline
\end{tabular}


Table 8. Comparison between B3LYP and B3LYP-D3 binding energies $(\mathrm{kJ} / \mathrm{mol})$ of cytosineTMZ dimers.

\begin{tabular}{|l|l|l|c|}
\hline Dimer & $\begin{array}{l}\text { B3LYP- } \\
\text { D3 }\end{array}$ & B3LYP & $\Delta$ BE \\
\hline C1 P & -67.73 & -27.85 & -39.88 \\
\hline C2 HB & -77.84 & -64.69 & -13.15 \\
\hline C3 P & -64.86 & -29.16 & -35.70 \\
\hline C4 S1 & -61.01 & -27.85 & -33.16 \\
\hline C5 S2 & -55.19 & 1.31 & -56.50 \\
\hline C6 HB & -72.63 & -57.91 & -14.72 \\
\hline C7 S2 & -51.03 & 10.79 & -61.82 \\
\hline C8 S2 & -49.13 & 8.57 & -57.70 \\
\hline C9 S1 & -54.69 & -3.22 & -51.47 \\
\hline C10 P & -45.86 & -12.87 & -33.02 \\
\hline C11 HB & -49.29 & -30.82 & -18.47 \\
\hline C12 HB & -46.00 & -34.18 & -11.82 \\
\hline
\end{tabular}

Table 9. Comparison between B3LYP and B3LYP-D3 binding energies $(\mathrm{kJ} / \mathrm{mol})$ of adenineTMZ dimers.

\begin{tabular}{|l|l|l|l|}
\hline Dimer & B3LYP-D3 & B3LYP & \multicolumn{1}{|c|}{$\Delta$ BE } \\
\hline A1 P & -65.06 & -27.67 & -37.39 \\
\hline A2 HB & -71.15 & -57.53 & -13.62 \\
\hline A3 S1 & -51.16 & 15.69 & -66.85 \\
\hline A4 S1 & -53.47 & 7.43 & -60.9 \\
\hline A5 S2 & -45.20 & 15.89 & -61.09 \\
\hline A6 S1 & -45.70 & 19.02 & -64.7 \\
\hline A7 S1 & -47.86 & 15.45 & -63.31 \\
\hline A8 S2 & -41.48 & 19.49 & -60.97 \\
\hline A9 P & -47.59 & -8.90 & -38.69 \\
\hline A10 S1 & -45.49 & 6.38 & -42.11 \\
\hline A11 HB & -55.21 & -42.31 & -12.9 \\
\hline
\end{tabular}


Table 10. Comparison between B3LYP and B3LYP-D3 binding energies $(\mathrm{kJ} / \mathrm{mol})$ of guanineTMZ dimers.

\begin{tabular}{|l|l|l|l|}
\hline Dimer & B3LYP-D3 & \multicolumn{1}{|c|}{ B3LYP } & \multicolumn{1}{|c|}{$\Delta$ BE } \\
\hline G1 P & -76.65 & -39.68 & -36.97 \\
\hline G2 HB & -81.58 & -65.54 & -16.04 \\
\hline G3 S2 & -54.77 & 15.28 & -70.05 \\
\hline G4 S1 & -58.63 & 12.14 & -70.77 \\
\hline G5 P & -64.67 & -29.17 & -35.50 \\
\hline G6 HB & -75.07 & -62.16 & -12.91 \\
\hline G7 S1 & -49.38 & 24.70 & -74.08 \\
\hline G8 HB & -67.02 & -52.82 & -14.20 \\
\hline G9 S1 & -53.22 & 2.04 & -55.26 \\
\hline G10 S1 & -46.06 & 24.28 & -70.34 \\
\hline G11 HB & -60.67 & -45.44 & -15.23 \\
\hline
\end{tabular}



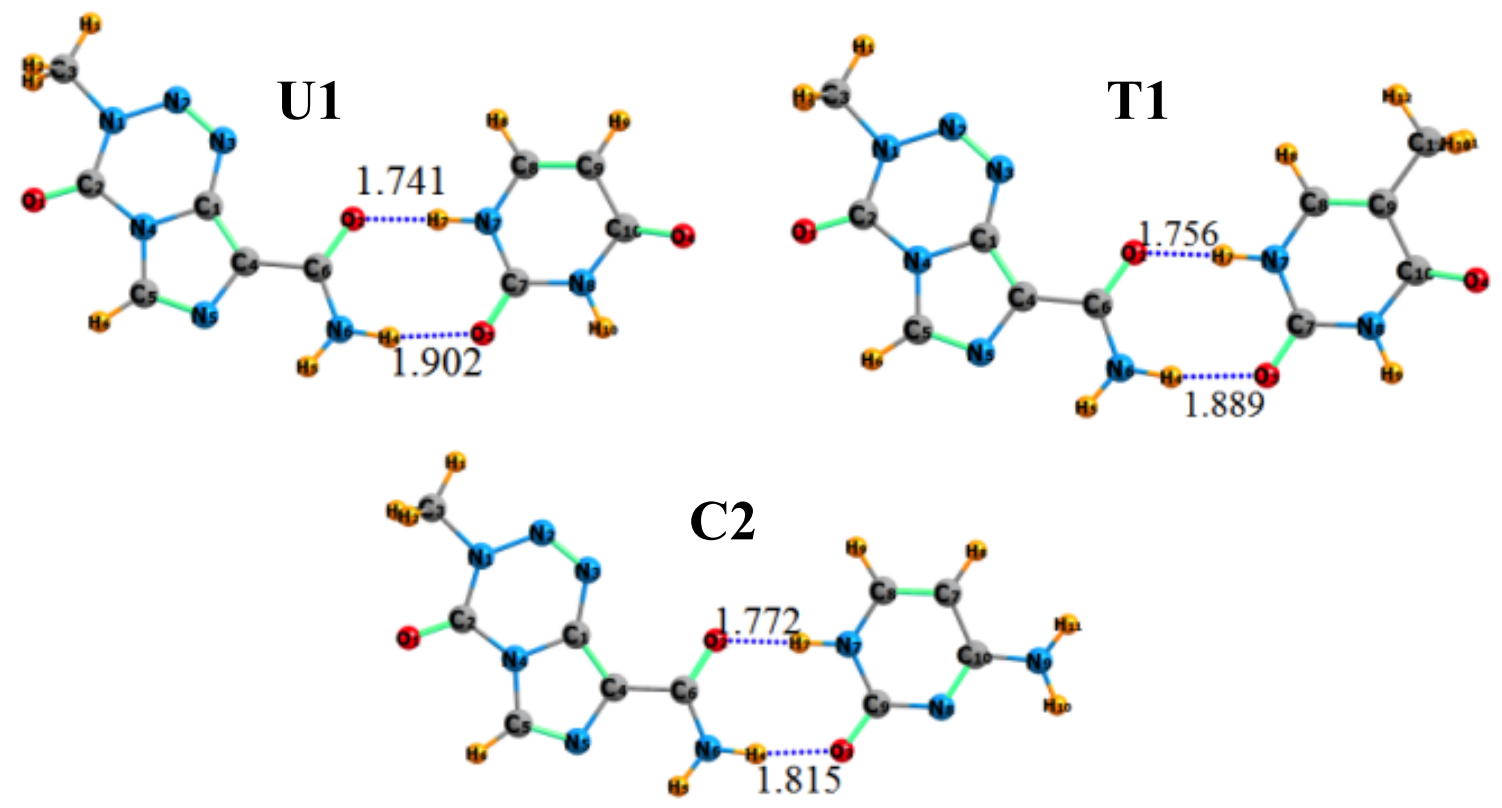

Fig. 1. Geometries of HB dimers of $\mathrm{U}, \mathrm{T}$, and $\mathrm{C}$ with TMZ. Distances in $\AA$. 

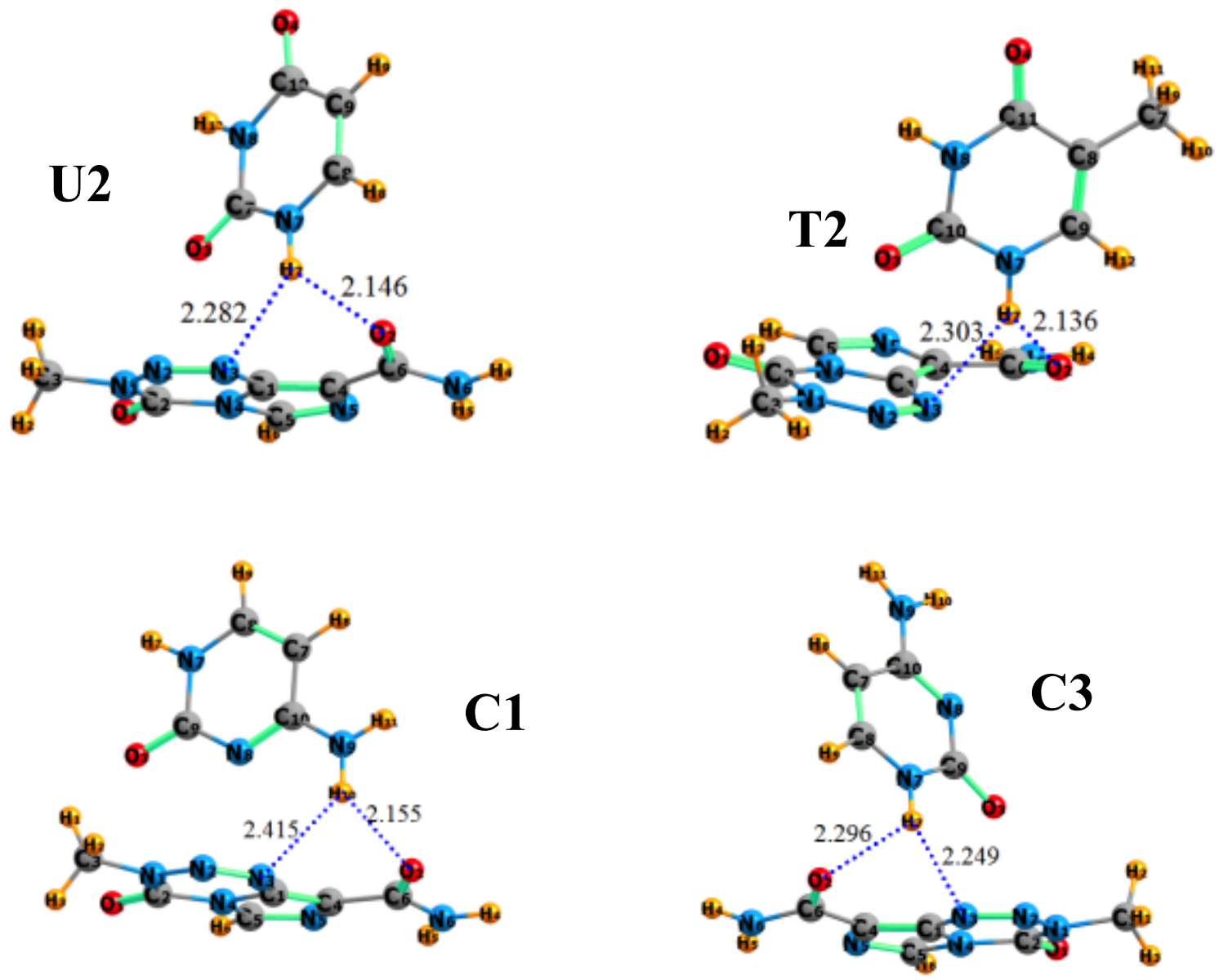

Fig. 2. Geometries of perpendicular (P) dimers of U, T, and C with TMZ. Distances in $\AA$. 

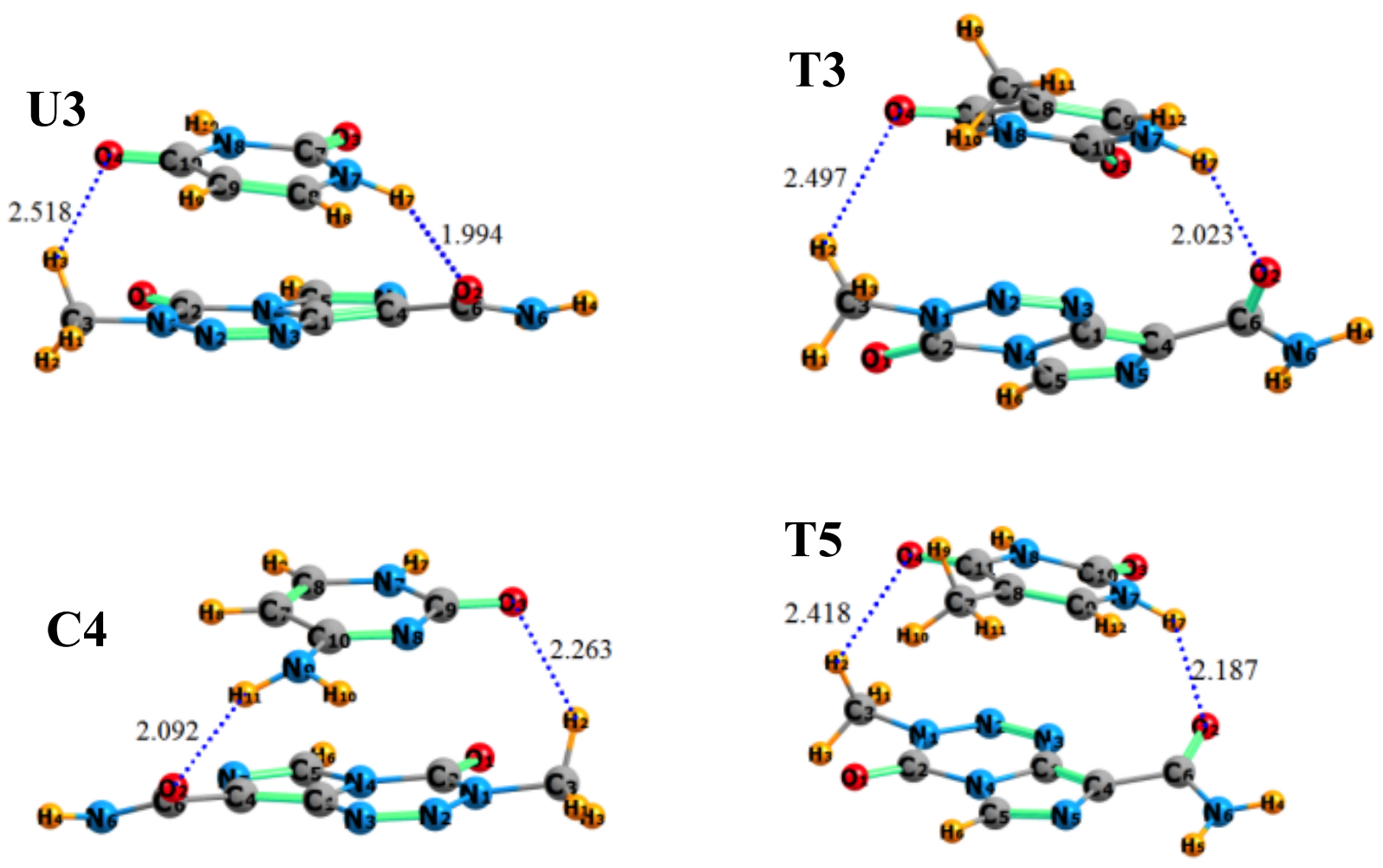

Fig. 3. Geometries of stacked (S1) dimers of U, T, and C with TMZ. Distances in $\AA$. 

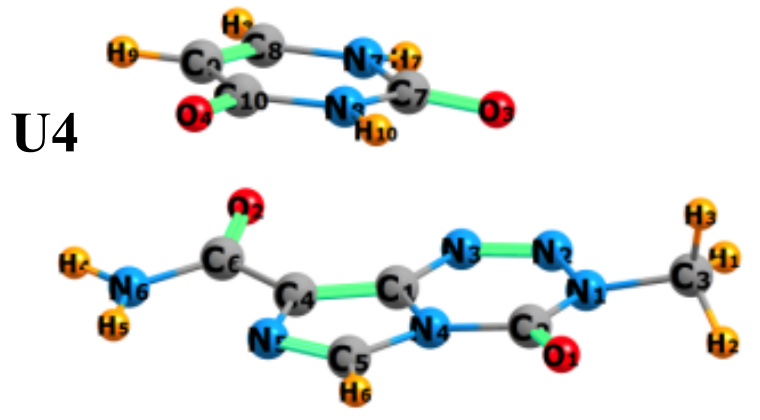
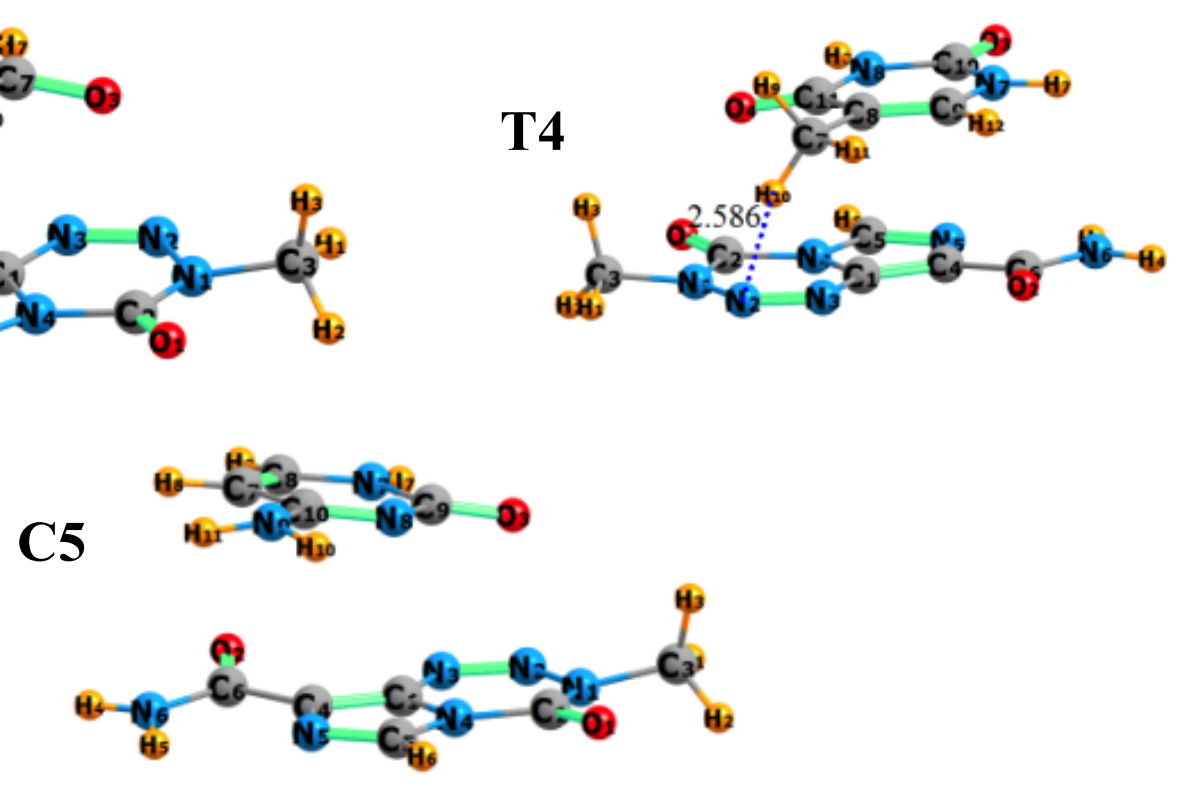

Fig. 4. Geometries of stacked (S2) dimers of U, T, and C with TMZ. Distances in $\AA$. 

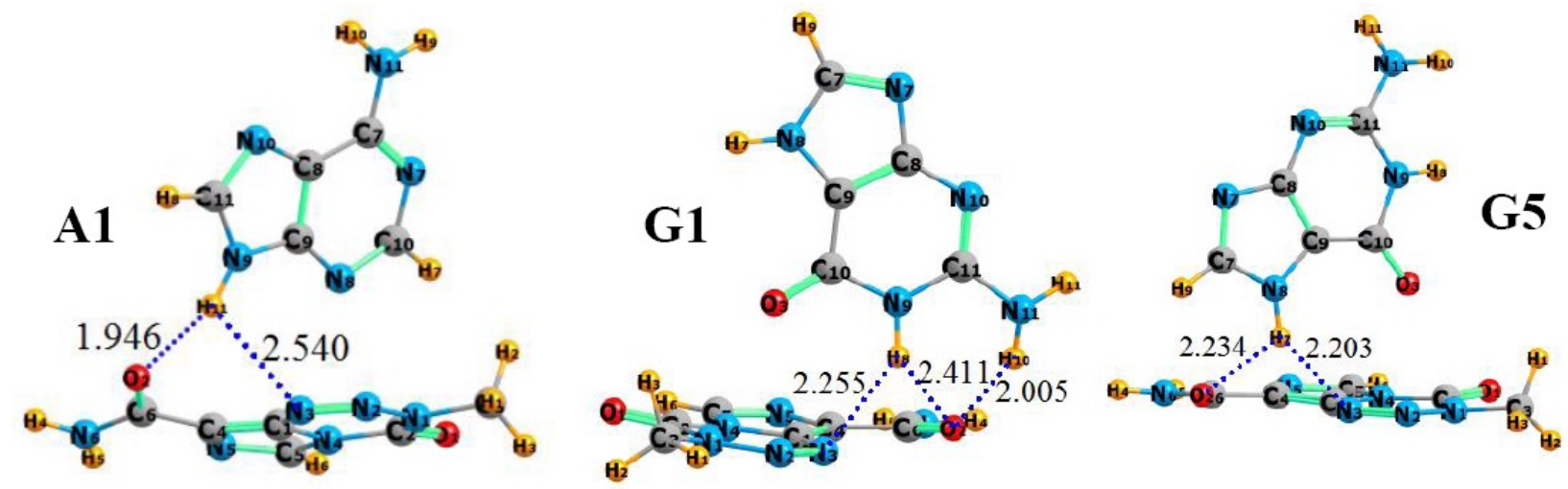

Fig. 5. Geometries of perpendicular (P) dimers of A and G with TMZ. Distances in $\AA$.
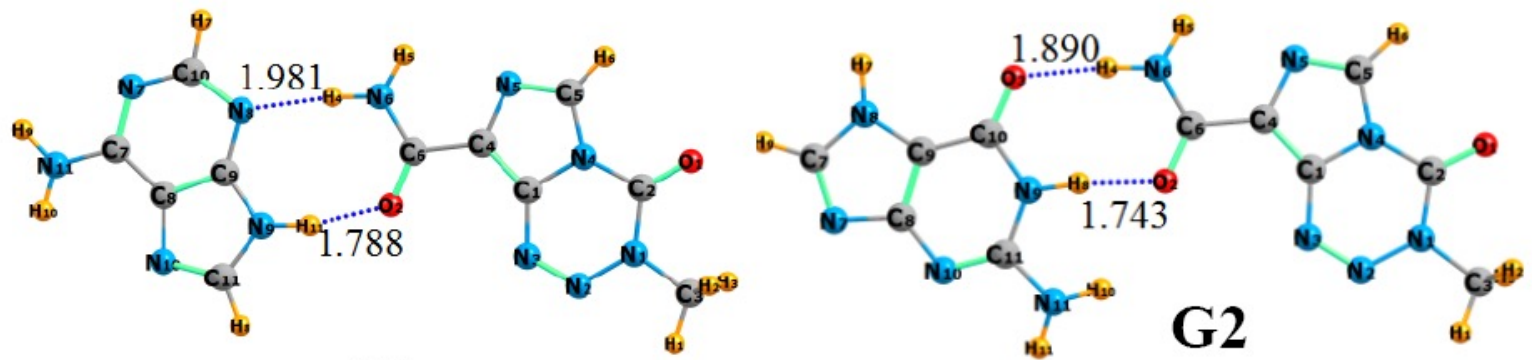

A2

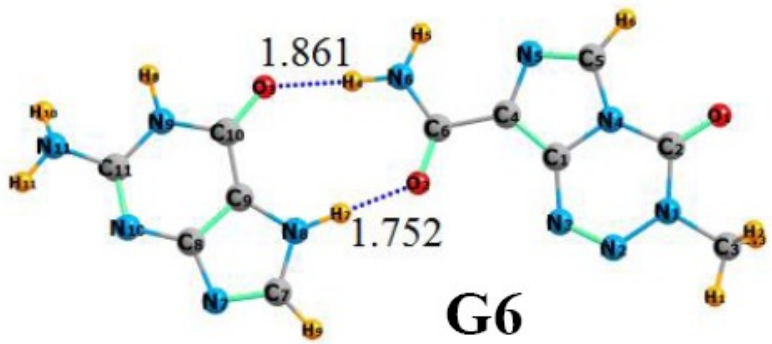

Fig. 6. Geometries of HB dimers of A and G with TMZ. Distances in $\AA$. 


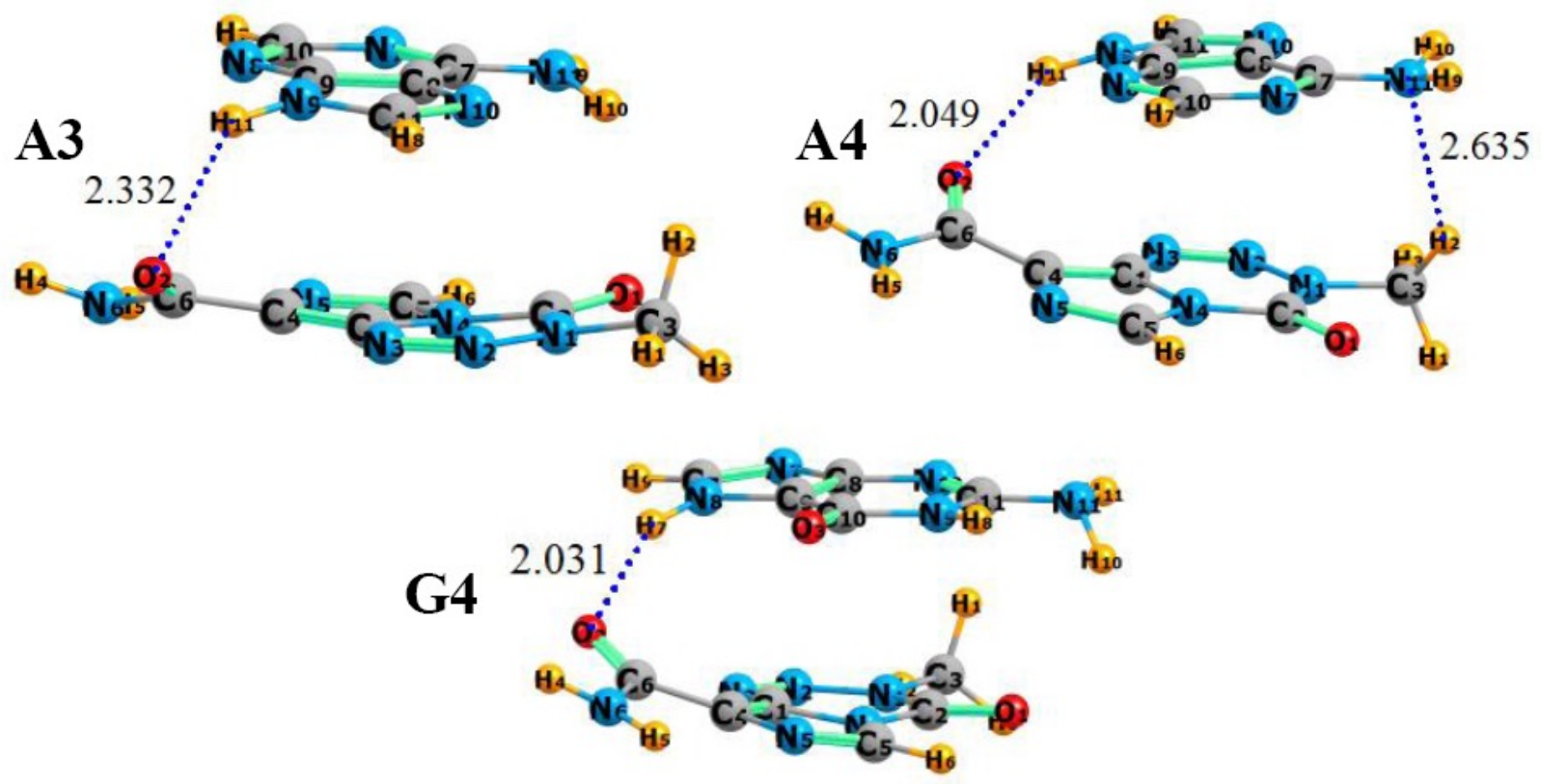

Fig. 7. Geometries of $\mathrm{S} 1$ dimers of $\mathrm{A}$ and $\mathrm{G}$ with TMZ. Distances in $\AA$.
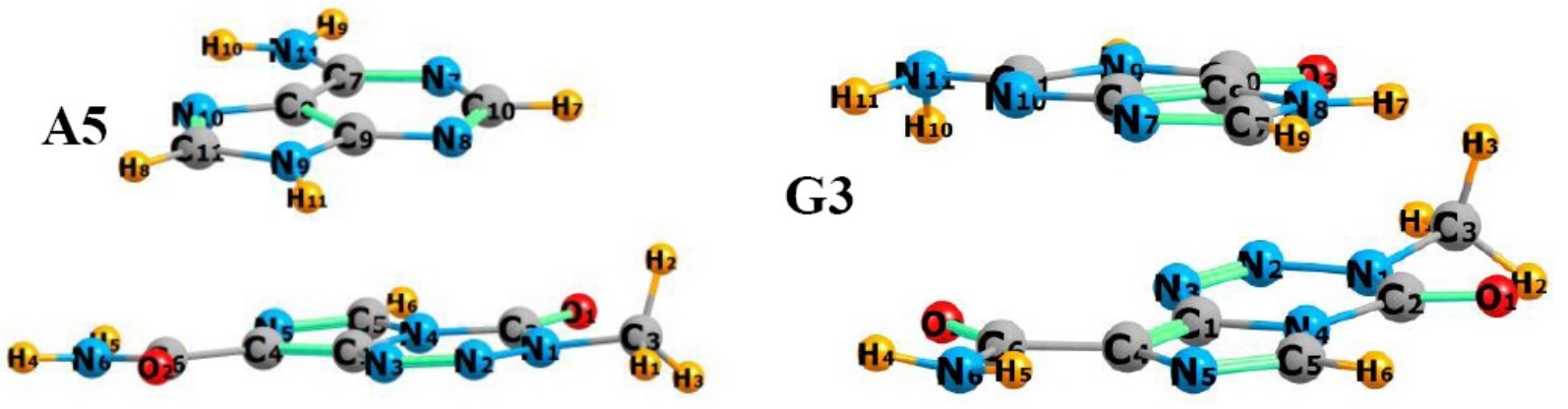

Fig. 8. Geometries of $\mathrm{S} 2$ dimers of $\mathrm{A}$ and $\mathrm{G}$ with TMZ. Distances in $\AA$. 


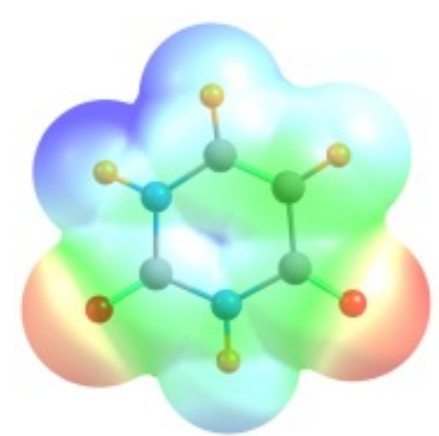

$\mathbf{U}$

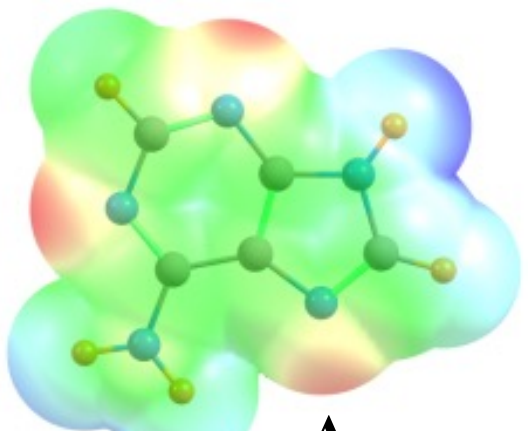

A

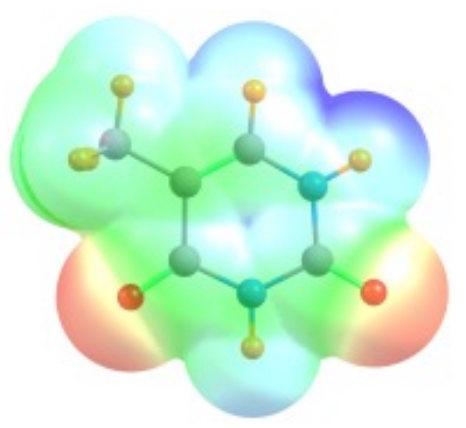

$\mathbf{T}$

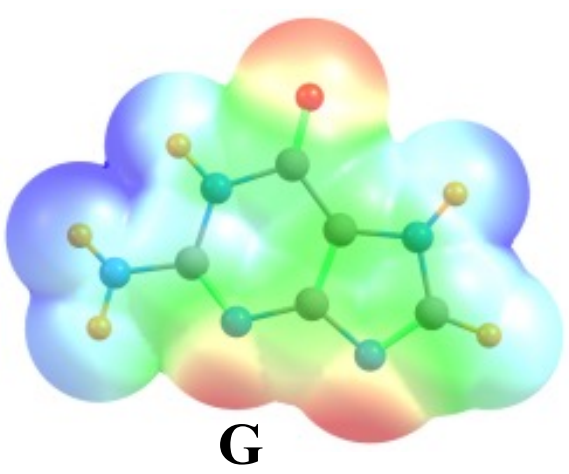

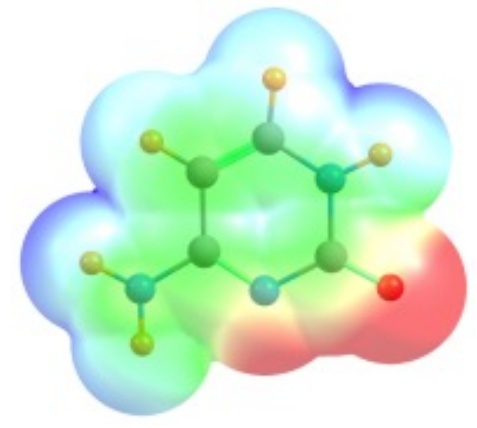

C

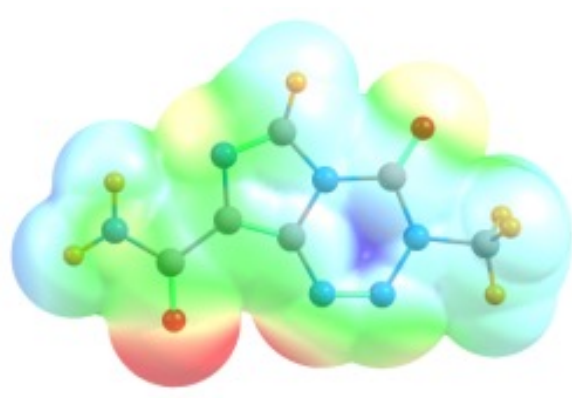

TMZ

Fig 9. Molecular electrostatic potential surrounding each of the five bases and TMZ on surface representing 1.5 times the van der Waals radius of each atom. Blue color indicates a potential of $+0.08 \mathrm{au}$, and red corresponds to -0.08 . 

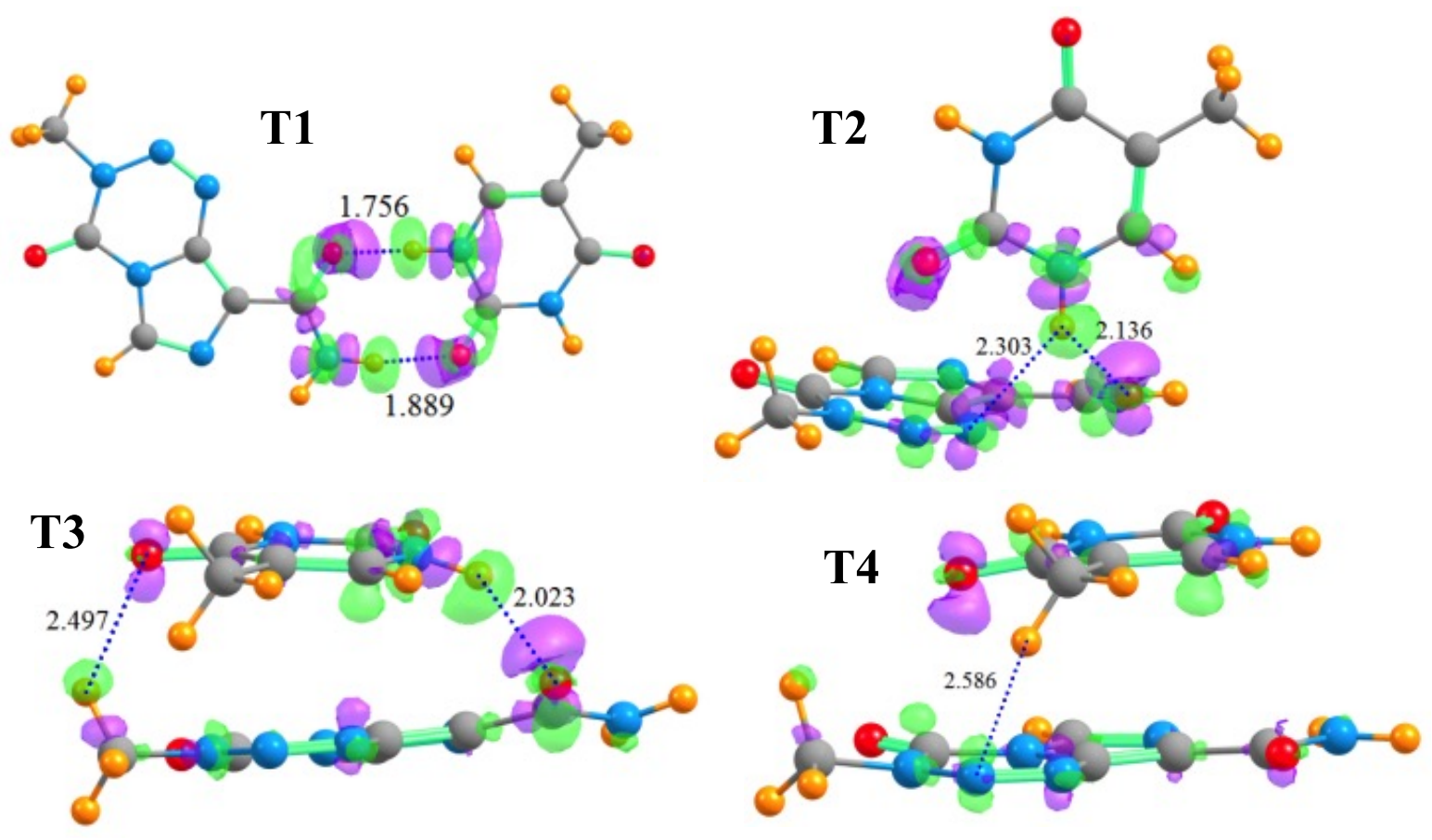

Fig 10. Electron density shifts occurring in the four indicated dimers of thymine with TMZ. Purple and green regions respectively indicate gain and loss upon formation of the complex, at the \pm 0.002 au contour. 


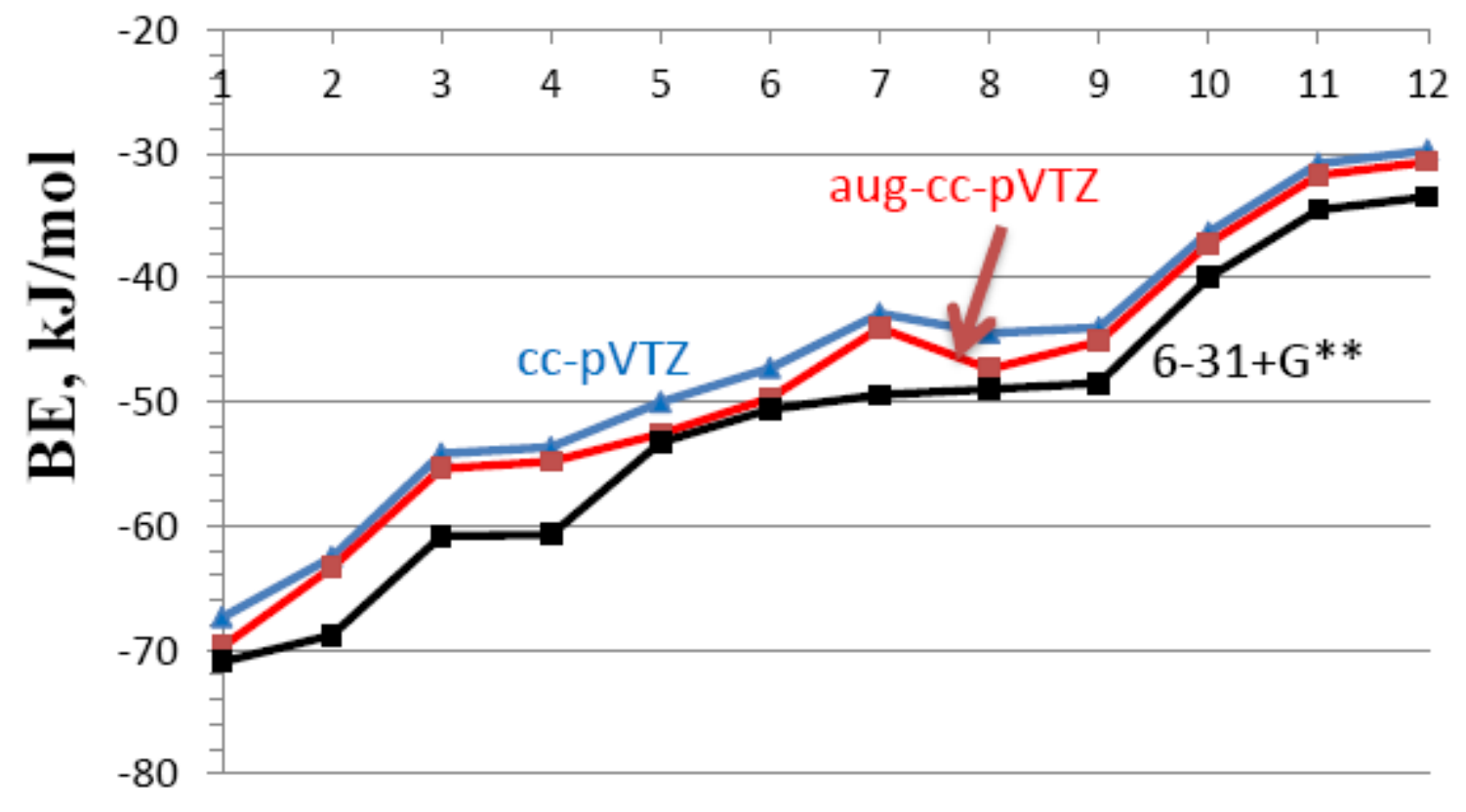

Fig 11. Binding energies computed with three different basis sets via the M06-2X functional for the 12 indicated uracil heterodimers with TMZ. 
table of contents graphic:

3 geometry types: nucleobase + temozolomide
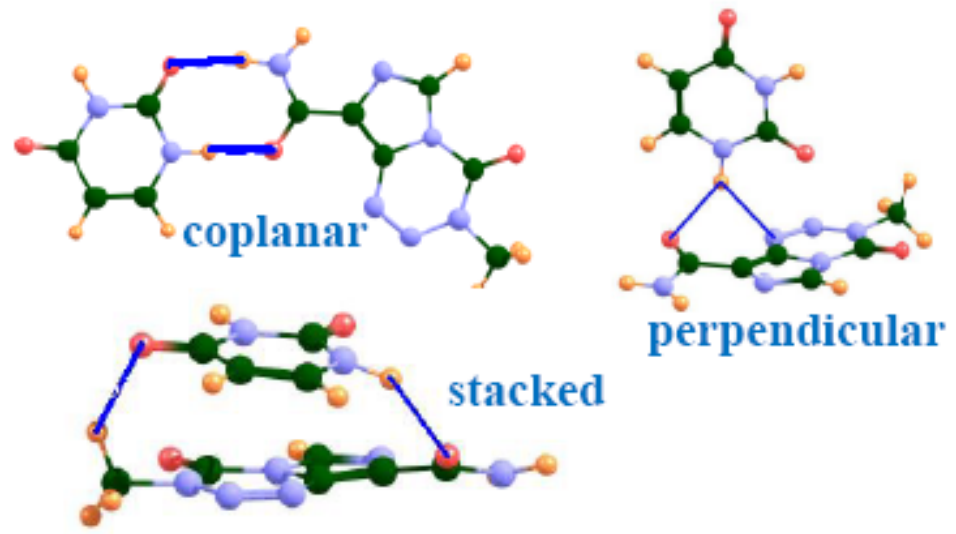